Research Article

\title{
Potential Source Regions and Transportation Pathways of Reactive Gases at a Regional Background Site in Northwestern China
}

\author{
Quanwei Zhao $\mathbb{D}^{1,2,3}$ Qing He $\mathbb{i D}^{1,3}$ Lili Jin $\mathbb{D}^{1,4}$ and Jianlin Wang ${ }^{3,5}$ \\ ${ }^{1}$ Institute of Desert Meteorology, China Meteorological Administration, Urumqi 830002, China \\ ${ }^{2}$ Xinjiang Meteorological Service Center, Urumqi 830002, China \\ ${ }^{3}$ Akedala Atmosphere Background Field Experiment Station of CMA, Urumqi 830002, China \\ ${ }^{4}$ Department of Atmospheric Sciences, Yunnan University, Kunming 650500, China \\ ${ }^{5}$ Akedala Atmosphere Background Station, Aletai 836500, China \\ Correspondence should be addressed to Qing He; qinghe@idm.cn and Lili Jin; jinll@idm.cn
}

Received 29 March 2021; Revised 21 May 2021; Accepted 12 June 2021; Published 3 July 2021

Academic Editor: Antonio Donateo

Copyright (C) 2021 Quanwei Zhao et al. This is an open access article distributed under the Creative Commons Attribution License, which permits unrestricted use, distribution, and reproduction in any medium, provided the original work is properly cited.

\begin{abstract}
Reactive gases $\left(\mathrm{O}_{3}, \mathrm{CO}, \mathrm{NO}_{2}\right.$, and $\left.\mathrm{SO}_{2}\right)$ were collected hourly at the Akedala regional background station in northwestern China during September 2017 to August 2018. Wind rose, cluster analysis, potential source contribution function (PSCF), and concentration-weighted trajectory (CWT) methods were adopted for identifying the transport pathways and potential source regions of these atmosphere components at Akedala. The average $\mathrm{O}_{3}, \mathrm{CO}, \mathrm{NO}_{2}$, and $\mathrm{SO}_{2}$ mixing ratios detected were $29.65 \pm 11.44 \mathrm{ppb}$, $123.78 \pm 73.35 \mathrm{ppb}, 3.79 \pm 0.98 \mathrm{ppb}$, and $4.59 \pm 0.88 \mathrm{ppb}$ during the observation period, and the statistical results of the monthly mean values revealed that there were differences during the highest pollution period, with $\mathrm{O}_{3}$ and CO mainly peaking in February, with mixing ratios of $38.03 \pm 7.10 \mathrm{ppb}$ and $208.50 \pm 106.50 \mathrm{ppb}$, respectively. Meanwhile, $\mathrm{NO}_{2}$ peaked in March $(4.51 \pm 0.54 \mathrm{ppb})$ and $\mathrm{SO}_{2}$ in January $(5.70 \pm 1.92 \mathrm{ppb})$. The most obvious diurnal variation of $\mathrm{CO}$ and $\mathrm{SO}_{2}$ was observed in the winter, with maximum levels reaching between 13:00 and 14:00. The diurnal variations of $\mathrm{O}_{3}$ exhibited low values during the night and maximum values in the afternoon (16:00-18:00). Diurnal variation was not significant in the case of $\mathrm{NO}_{2}$. Cluster analysis showed that six main paths affected the Akedala atmosphere. In turn, the PSCF and CWT analysis results indicated that the Akedala reactive gas was affected by both local and foreign sources. The high PSCF value of the reactive gas potential source areas appeared in eastern Kazakhstan, northern Xinjiang, Western Mongolia, and Southern Russia. The WCWT (weighted concentration-weight trajectory) values of $\mathrm{CO}$ and $\mathrm{SO}_{2}$ in winter were the highest, totaling $180-240 \mathrm{ppb}$ and 5-6.5 ppb, respectively. The WCWT value of $\mathrm{O}_{3}$ in the spring and summer was higher than that in the autumn and winter. The main source area of $\mathrm{O}_{3}$ was about 32-36 ppb in the spring and summer, and the main source area of $\mathrm{NO}_{2}$ in the summer had a low WCWT value of 3-3.5 ppb, whereas the $\mathrm{NO}_{2}$ WCWT value was concentrated at $4-4.5 \mathrm{ppb}$ in the other seasons.
\end{abstract}

\section{Introduction}

Reactive gases are strong chemical reaction substances in the Earth's lower atmosphere, with lifetimes between a few hours and a few months [1]. Among these, ozone $\left(\mathrm{O}_{3}\right)$, sulfur dioxide $\left(\mathrm{SO}_{2}\right)$, carbon monoxide $(\mathrm{CO})$, and nitrogen dioxide $\left(\mathrm{NO}_{2}\right)$ are important reactive gases that present dangers for eco-environments and human health $[2,3]$, and can also catalyze atmospheric chemical reactions, which are an important source of highly reactive atoms and free radicals $[4,5]$. They are also the preferred gaseous pollutants recommended by the World Meteorological Organization and China $[6,7]$. In addition to the effects of natural and manmade sources on atmospheric concentrations of $\mathrm{SO}_{2}, \mathrm{NO}_{2}$, $\mathrm{O}_{3}$, and $\mathrm{CO}$, regional- and global-scale atmospheric transport also affect atmospheric concentrations of these species, 
which can lead to changes in the climate system. For these reasons, these are currently popular research topics in the fields of Earth and environmental science [8-10].

With the rapid economic development and the acceleration of industrialization, man-made emissions of reactive gases have sharply increased. However, growth contribution to different regions also differs, and reactive gas levels and potential sources vary greatly among geographical locations in Asia, as shown in Table 1. For China, specifically, many scholars have studied reactive gases in areas with highly polluting emissions, such as cities $[11,12]$, road traffic $[13,14]$, and ports $[15,16]$. There are relatively few reports on the background concentration of reactive gases compared to highly polluting areas such as cities, and field research on atmospheric constituents of regional background sites can not only provide valuable information on the impact of human activities, but also help illuminate the scope of regional air pollution. In addition, the general population around the background station is small, and the man-made source and sink densities are scarce. Reactive gases in these environments are determined by natural processes, such as turbulent exchange and advective transport [17]. These background sites are also recognized as climate-sensitive hotspots, and they offer a better perception of changes to the surrounding environment [18], so it is a good choice to use background stations to track the source of the reactive gas. Many methods are used to investigate the location or direction of emission sources relative to observatories, wind roses, or CBPF (conditional bivariate probability function); matching wind data (wind speed, wind direction) with air pollutants values is superior to identifying local pollution sources [19-22]. Mangia et al. [23] identified areas of air pollutants emitted from different sources by analyzing prevailing winds and measurements of $\mathrm{NO}_{2}$ and $\mathrm{SO}_{2}$ in Taranto, Italy, finding that higher values of $\mathrm{NO}_{2}$ and $\mathrm{SO}_{2}$ were observed when the station was downwind of the industrial site. Pollution wind roses indicated the two prevalent wind directions that influenced the dispersion of air pollutants $\left(\mathrm{CO}, \mathrm{NO}_{2}, \mathrm{CH}_{4}\right.$, and $\left.\mathrm{SO}_{2}\right)$ in Eleme, Rivers State, Nigeria. The higher pollutant values were associated with northeast wind in the dry season and southwest wind in the rainy season [24]. Li et al. [25] studied regional transportation of air pollutants in Northeast China Plain. Their studies revealed that high $\mathrm{O}_{3}$ mixing ratios occurred in presence of strong winds $(>3 \mathrm{~m} / \mathrm{s})$ but were independent of wind direction at different cities of Northeast China. Lagrangian-integrated trajectory (HYSPLIT) based on numerical simulation has been widely used for evaluating longrange transported pollutants and shows excellent potential [26]; on the basis of this, cluster analyses have been conducted, along with potential source contribution factor analyses (PSCF), concentration-weighted trajectory (CWT) method, and other trajectory analysis methods [27, 28]. OuYang et al. [29] use backward trajectory software to reveal the source of air masses from alpine atmospheric background stations in central Taiwan, indicating that air masses from the westerly belt are predominant in spring and winter, leading to higher CO concentrations. Vellingiri et al. [30] calculated the air quality transmission path in Seoul, South
Korea, by using the TrajStat trajectory statistical function of HYSPLIT, and found that the high mixing ratio of $\mathrm{NO}_{2}$ (greater than $60 \times 10^{-9}$ ) emanated from Mongolia, Russia, and northern China. Kasparoglu et al. [31] employed cluster analysis to evaluate air quality in the Marmara region of Turkey; high $\mathrm{O}_{3}$ concentrations often seemed to appear in the trajectory clusters of air masses, mainly from the northeast and northern directions, accounting for about $80 \%$ of the totals.

In this study, drawing on the field observation data of reactive gases $\left(\mathrm{O}_{3}, \mathrm{SO}_{2}, \mathrm{CO}\right.$, and $\left.\mathrm{NO}_{2}\right)$ at the Akedala Atmospheric Background Station in Xinjiang, China, from September 2017 to August 2018, the change characteristics of reactive gases on multiple time scales are analyzed and wind rose, cluster analysis, potential source contribution factor analysis, and concentration-weighted analysis employed. The wind rose model was applied to identify possible directions of local pollution sources. The cluster analysis revealed the characteristics of the Akedala reactive gases across different seasons and the main transportation routes, whereas PSCF and CWT were primarily used to identify the potential pollution source areas of reactive gases in northwestern China and their contribution levels.

\section{Data and Methodology}

2.1. Site and Data. The Akedala Regional Atmospheric Background Station $\left(47^{\circ} 10^{\prime} \mathrm{N}, 87^{\circ} 58^{\prime} \mathrm{E}, 562 \mathrm{~m}\right)$ is part of the GAW program, which is managed by the China Meteorological Administration, and is located in western Fuhai County, in the Altay region of Xinjiang in northwestern China, as is shown in Figure 1. Alluvial flatlands surround the site for approximately $50 \mathrm{~km}$, along with the Gobi valleys of the Irtysh and Ulungur Rivers. The terrain is wide and flat, with the tall Altai Mountains in the northeast, the Sawyer Mountains in the southwest, and Junggar Basin in the south. In terms of climate characteristics, the area features a typical continental temperate and semiarid climate, with northwesterly and easterly winds prevailing throughout the year, with hot and dry conditions in summer, cold and dry ones in the winter, and large temperature differences between the day and night. $\mathrm{O}_{3}, \mathrm{NO}_{2}, \mathrm{CO}$, and $\mathrm{SO}_{2}$ have been routinely measured at Akedala since 2009, offering basic information on the sources and sinks of reactive gases in the area.

The monitoring instruments are installed in an airconditioned laboratory on the top floor of a building $10 \mathrm{~m}$ in height. The observation period spanned August 1st, 2017, to September 31st, 2018, totaling 365 days, and a valid monthly average was required to be based on at least 27 valid daily averages over one month (with at least 25 valid daily averages in February); valid daily averages of air pollutants at each site were required to be based on at least 20 valid hourly averages in one day. The seasons were divided as follows: autumn (September-November), winter (December-February), spring (March-May), and summer (June-August). The instruments used for measuring the concentrations of $\mathrm{SO}_{2}, \mathrm{NO}_{2}, \mathrm{O}_{3}$, and $\mathrm{CO}$ were for continuous automatic analysis, were produced by Australia Ecotech Inc., and 
TABLe 1: Reactive gases $\left(\mathrm{O}_{3}, \mathrm{CO}, \mathrm{NO}_{2}\right.$, and $\left.\mathrm{SO}_{2}\right)$ mixing ratios from other sites in Asia (ppb).

\begin{tabular}{|c|c|c|c|c|c|c|c|}
\hline Sampling site & Year & $\begin{array}{l}\mathrm{O}_{3} \text { mixing } \\
\text { ratios }\end{array}$ & $\begin{array}{l}\mathrm{CO} \text { mixing } \\
\text { ratios }\end{array}$ & $\begin{array}{l}\mathrm{NO}_{2} \text { mixing } \\
\text { ratios }\end{array}$ & $\begin{array}{l}\mathrm{SO}_{2} \text { mixing } \\
\text { ratios }\end{array}$ & Potential source regions & References \\
\hline Seoul, Korea & 2001 to 2014 & - & 619.10 & 37.00 & 5.34 & $\begin{array}{c}\text { Eastern and } \\
\text { northeastern China }\end{array}$ & [9] \\
\hline $\begin{array}{l}\text { Wuhan, Central } \\
\text { China }\end{array}$ & $\begin{array}{l}\text { March } 2013 \text { to } \\
\text { February } 2014\end{array}$ & 29.11 & 559.79 & 26.78 & 11.33 & $\begin{array}{c}\text { Shanxi, Jiangxi, Anhui, } \\
\text { Henan, Hebei, and } \\
\text { Hunan provinces in } \\
\text { China }\end{array}$ & {$[32]$} \\
\hline $\begin{array}{l}\text { Dinghushan } \\
\text { background station, } \\
\text { South China }\end{array}$ & $\begin{array}{c}\text { January } 2013 \\
\text { to December } \\
2013 \\
\end{array}$ & $24.60 \pm 23.90$ & $348 \pm 185$ & - & $4.00 \pm 4.80$ & Pearl river delta region & {$[33]$} \\
\hline $\begin{array}{l}\text { Gongga mountain, } \\
\text { southwestern China }\end{array}$ & $\begin{array}{c}\text { January } 2017 \\
\text { to December } \\
2017\end{array}$ & $34.91 \pm 10.28$ & $152.67 \pm 101.78$ & $0.83 \pm 0.63$ & $0.17 \pm 0.21$ & $\begin{array}{c}\text { Chongqing, Hubei, } \\
\text { Hunan, Guizhou, } \\
\text { Guangxi provinces in } \\
\text { China, India, Pakistan }\end{array}$ & {$[34]$} \\
\hline $\begin{array}{l}\text { Menyuan, } \\
\text { northwestern China }\end{array}$ & $\begin{array}{c}\text { September } \\
2013 \text { to } \\
\text { October } 2013 \\
\end{array}$ & $56.59 \pm 3.22$ & $25.90 \pm 27.74$ & $1.95 \pm 1.02$ & $1.15 \pm 0.70$ & $\begin{array}{c}\text { Xining and Lanzhou in } \\
\text { China }\end{array}$ & {$[35]$} \\
\hline $\begin{array}{l}\text { Shangdianzi } \\
\text { background station, } \\
\text { northern China }\end{array}$ & $\begin{array}{c}\text { January } 2006 \\
\text { to December } \\
2006 \\
\end{array}$ & $30.9 \pm 19.8$ & $742 \pm 558$ & $11.5 \pm 10.8$ & $7.6 \pm 10.2$ & $\begin{array}{c}\text { The North China Plain } \\
\text { region }\end{array}$ & {$[36]$} \\
\hline $\begin{array}{l}\text { An urban site (CSIR- } \\
\text { NPL) of Delhi, India }\end{array}$ & $\begin{array}{c}\text { January } 2012 \\
\text { to December } \\
2014 \\
\end{array}$ & $29.5 \pm 7.3$ & $1820 \pm 520$ & - & - & $\begin{array}{l}\text { The Indo-Gangetic } \\
\text { Plain (IGP) }\end{array}$ & {$[37]$} \\
\hline $\begin{array}{l}\text { An urban city } \\
\text { (Bhubaneswar) of } \\
\text { Odisha, India }\end{array}$ & $\begin{array}{c}\text { December } \\
2009 \text { to } \\
\text { January } 2011 \\
\end{array}$ & $20-85$ & - & - & - & $\begin{array}{l}\text { Indo-Gangetic Plains } \\
\text { (IGP) and western part } \\
\text { of Indian peninsula }\end{array}$ & {$[38]$} \\
\hline $\begin{array}{l}\text { An urban site (IARI) } \\
\text { of Delhi, India }\end{array}$ & $\begin{array}{c}\text { January } 2011 \\
\text { to December } \\
2015 \\
\end{array}$ & - & $1800 \pm 500$ & $18.6 \pm 4.6$ & - & $\begin{array}{c}\text { NCR, Haryana, Punjab, } \\
\text { Rajasthan, and Uttar } \\
\text { Pradesh } \\
\end{array}$ & [39] \\
\hline $\begin{array}{l}\text { A semiurban location } \\
\text { (Patiala), India }\end{array}$ & $\begin{array}{c}\text { December } \\
2013 \text { to } \\
\text { November } \\
2014 \\
\end{array}$ & 39 & - & - & - & $\begin{array}{l}\text { Parts of India such as } \\
\text { Punjab, Haryana, and } \\
\text { Rajasthan and parts of } \\
\text { Pakistan }\end{array}$ & {$[40]$} \\
\hline $\begin{array}{l}\text { An island (Langkawi) } \\
\text { of Andaman sea, } \\
\text { Malaysia }\end{array}$ & $\begin{array}{c}\text { January } 1999 \\
\text { to December } \\
2011 \\
\end{array}$ & $16.7 \pm 12.8$ & $494 \pm 324$ & $5.20 \pm 3.60$ & $1.50 \pm 0.80$ & $\begin{array}{l}\text { Northern Peninsular } \\
\text { Malaysia, Sumatra, and } \\
\text { Indochina }\end{array}$ & {$[41]$} \\
\hline $\begin{array}{l}\text { A background station } \\
\text { (Jerantut) of Pahang, } \\
\text { Malaysia }\end{array}$ & $\begin{array}{c}\text { January } 1997 \\
\text { to December } \\
2011\end{array}$ & $12.6 \pm 8.6$ & $326.0 \pm 32.0$ & $2.4 \pm 0.5$ & $1.9 \pm 0.1$ & $\begin{array}{c}\text { Urbanized and } \\
\text { industrial areas such as } \\
\text { Kuala Lumpur city } \\
\text { center and Jerantut city }\end{array}$ & {$[42]$} \\
\hline $\begin{array}{l}\text { A big city (Bursa), } \\
\text { Turkey }\end{array}$ & $\begin{array}{c}\text { January } 2016 \\
\text { to December } \\
2017\end{array}$ & $24.26 \pm 11.98$ & $335.57 \pm 98.08$ & $22.80 \pm 8.08$ & $2.66 \pm 1.19$ & $\begin{array}{l}\text { Industrial activities, } \\
\text { combustion emissions, } \\
\text { and traffic in the } \\
\text { surrounding areas }\end{array}$ & {$[43]$} \\
\hline $\begin{array}{l}\text { An urban site } \\
\text { (Kanpur), India }\end{array}$ & $\begin{array}{c}\text { June } 2009 \text { to } \\
\text { May } 2013\end{array}$ & $27.9 \pm 17.8$ & $721 \pm 403$ & - & $3.0 \pm 3.1$ & 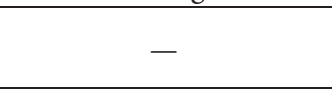 & {$[44]$} \\
\hline $\begin{array}{l}16 \text { cites in Xinjiang, } \\
\text { western China }\end{array}$ & $\begin{array}{l}\text { January } 2013 \\
\text { to June } 2019\end{array}$ & $25.83-30.50$ & $529.26-671.76$ & $12.81-15.47$ & $3.84-6.29$ & $\begin{array}{l}\text { Xinjiang region and } \\
\text { surrounding countries }\end{array}$ & {$[45]$} \\
\hline
\end{tabular}

corresponded to EC/ML 9850, 9841B, 9810B, and 9830B, respectively.

Strict quality control was implemented during the instrument observation period, such as zero/span checks and multipoint calibrations. Zero/span checks were used to regularly check the drift in the instrument response. Multipoint calibration established the response relationship between the standard gas concentration and analytical instrument. The correct observed value of the instrument in terms of the concentration was based on standard gas. In addition, the quality of the original collected observation data was further controlled, and the blank value and negative concentration data were eliminated, effectively guaranteeing the quality of the monitoring data. The meteorological data for the backward trajectory was obtained from the global Data Assimilation System (GDAS) provided by the 


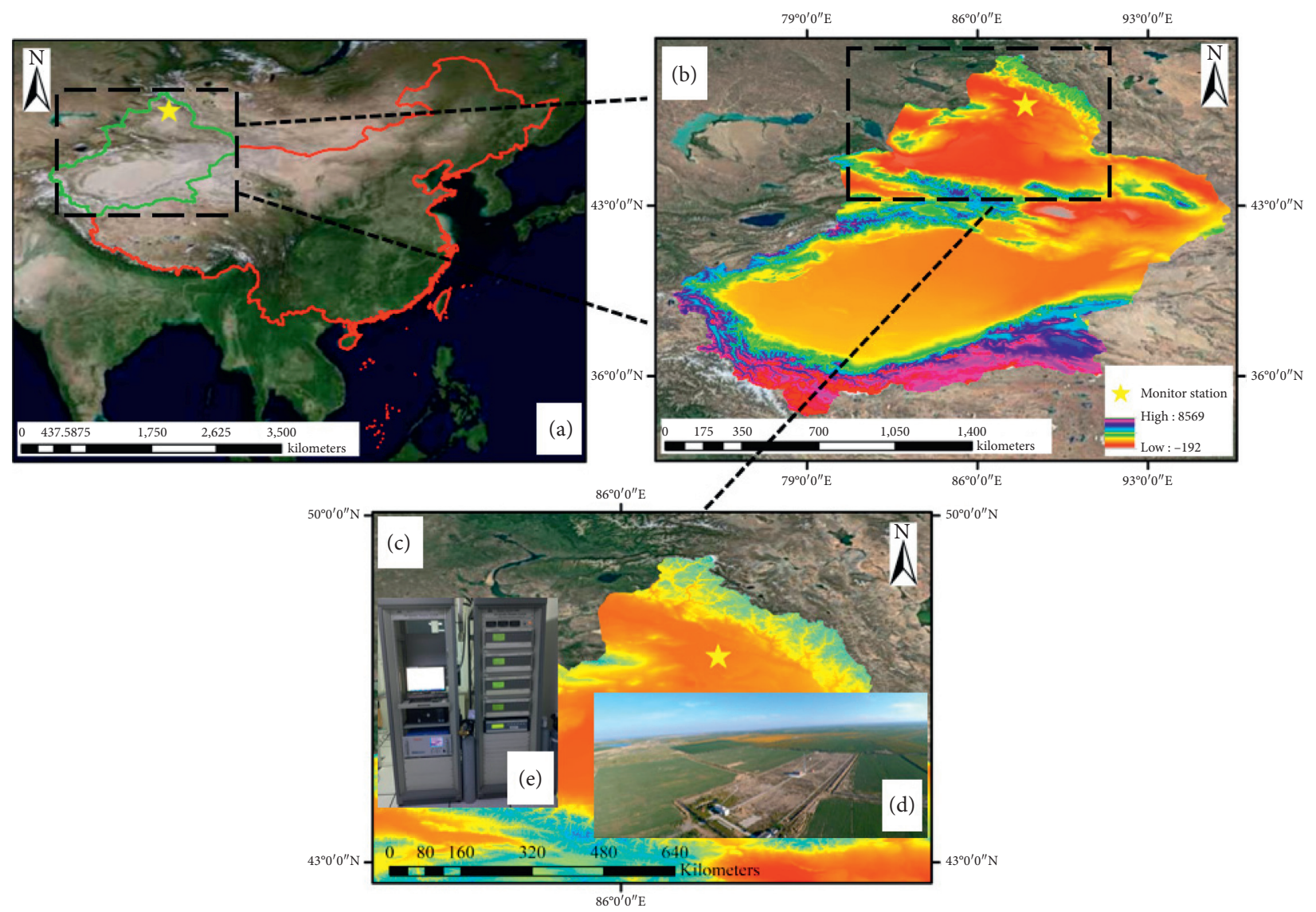

FIGURE 1: Location of the Akedala regional atmosphere background station, with the yellow star representing the location of Akedala: (a) geographical location of Xinjiang, China; (b) elevation map of Xinjiang; (c) broadened version of the study area; (d) picture of a UAV flying over Akedala; (e) observation equipment at the Akedala site.

National Center for Environmental Forecasting (NCEP) of the United States (interval: $1 \mathrm{~h}$, horizontal resolution $0.5^{\circ} \times 0.5^{\circ}$ ), and the meteorological elements included temperature, air pressure, relative humidity, and vertical and horizontal wind speed.

\subsection{Backward Trajectory Model and Clustering Analysis.} The HYSPLIT model is a professional model system jointly developed by the National Oceanic and Atmospheric Administration (NOAA) Air Resources Laboratory (ARL) to calculate and analyze the source, transmission, and diffusion trajectories of atmospheric pollutants. The model is capable of processing multiple meteorological element input fields, multiple physical processes, and functions of different types of emission sources [46]. In this study, the backward trajectory analysis was performed using the TrajStat software (http:// www.meteothinker.org/), which is an application developed for air mass trajectory visualization and statistical analysis. The TrajStat uses a geographical information system technique for data management and includes the Hybrid Single-Particle Lagrangian-Integrated Trajectory (HYSPLIT) model [28]. To determine the passing routes of air masses before they reach Akedala, the $48 \mathrm{~h}$ backward trajectories were calculated. The NCEP's GDAS half-degree outputs from NOAA's ARL were used to drive our backward trajectory calculation. The simulations were run at every hour. The end point was set to $500 \mathrm{~m}$ above sea level due to the friction and turbulence effects near the ground, and the choice of a low reaching height may lead to inaccuracies in the trajectory calculation [47], and the height of $500 \mathrm{~m}$ can reflect the regional fluidity characteristics of the airflow and can also reduce the influence of the surface friction. This height layer can effectively represent a well-mixed convective boundary layer and is suitable for regional transportation investigations [48].

Cluster analysis is a multivariate statistical analysis technique that utilizes similarity or difference indicators to mathematically determine the relationship between samples and divide the trajectory data into different clusters according to this. Trajectory cluster analysis is carried out on the basis of the TrajStat software, which features two clustering methods, namely, angular distance and Euclidean distance. Euclidean distance is often used to define latitude and longitude positions as variables for the distance between two trajectories. Its main disadvantage is that if two backward trajectories have the same path of motion but differing speeds, they will be divided into two different categories. In this study, we utilize the angular distance algorithm to cluster the airflow trajectory to Akedala and calculate the reactive gas concentration corresponding to the airflow over different seasons. The main reason for using 
angular distance clustering was to distinguish the direction of the reactive gas arriving at Akedala.

\subsection{Potential Source Contribution Function (PSCF).} PSCF, combining airflow trajectory and hourly pollutant concentrations, was measured at the receptor region and used in this study. This technique has frequently been used to identify the probable locations of emission sources that affect pollutant loadings in the study region [49]. As Akedala is a relatively clean background station in western China, the mean value of hourly data on reactive gases is taken as the threshold value [50]. In other words, when the mixing ratio of the reactive gas corresponding to the airflow trajectory through the grid exceeds the hourly mean value, the trajectory is considered a pollution trajectory, and the PSCF value is calculated by determining the number of pollution trajectories. The analytical field is divided into small equal grid cells $(i, j)$. The PSCF value for a single grid cell is then calculated by counting each trajectory segment endpoint that terminates within that grid cell [51] as follows:

$$
\operatorname{PSCF}_{i j}=\frac{m_{i j}}{n_{i j}}
$$

where $i$ and $j$ denote the latitude and longitude, respectively; $m_{i j}$ is the number of back-trajectory endpoints at the grid cell $(i, j)$ corresponding to the measured mixing ratios of reactive gases higher than a user-determined threshold criterion; and $n_{i j}$ is the total number of end points that fall at the $i$ and $j$ cell. The higher the PSCF value, the higher the possibility of the areas being potential sources of reactive gases at the receptor sites. In order to reduce the uncertainty in a grid cell with a small number of endpoints, an arbitrary weight function $W_{i j}$, defined by (2), was multiplied into the PSCF value [52]:

$$
W_{i j}= \begin{cases}1.0, & n_{i j}>80 \\ 0.70, & 20<n_{i j} \leq 80, \\ 0.42, & 10<n_{i j} \leq 20 \\ 0.05, & n_{i j} \leq 10 .\end{cases}
$$

2.4. Concentration-Weighted Trajectory (CWT). PSCF can only reflect the proportion of each grid pollution trajectory, and it is somewhat difficult to separate moderate sources from strong ones for a PSCF method in which grid cells can have the same PSCF value when sample mixing ratios are either only slightly higher or much higher than the criterion. In order to overcome this limitation, this paper employs the concentration-weighted trajectory analysis method (CWT) to calculate the value weight of the airflow trajectory in the potential source area [27] and then quantitatively analyzes the degree of pollution for different trajectories and potential source areas. The CWT calculation method is shown as follows:

$$
C_{i j}=\frac{1}{\sum_{n=1}^{M} \beta_{i j n}} \sum_{n=1}^{M} C_{n} \beta_{i j n}
$$

where $C_{i j}$ is the mean weighted value in the $(i, j)$ cell, $n$ is the index of the trajectory, $M$ represents the total number of trajectories, $C_{n}$ is the measured reactive gas mixing ratio observed at the arrival of trajectory $n$, and $\beta_{i j n}$ is the time spent in the grid cell $(i, j)$ by trajectory $n$. A high $C_{i j}$ value indicated that the high potential emission sources in the grid cell can result in high polluted values at the receptor site. Like the PSCF method, the CWT method also employs the arbitrary weight function to eliminate grid cells with few endpoints.

\section{Results}

3.1. Variation Characteristics of Reactive Gas Mixing Ratio in the Akedala Atmospheric Background Station. As is shown in Figure 2, in general, the hourly average maximum mixing ratio of $\mathrm{O}_{3}$ did not exceed $70 \mathrm{ppb}$, the overall average was $29.65 \pm 11.44 \mathrm{ppb}$, and the median was $29.87 \mathrm{ppb}$. Compared to other background sites in China, the $\mathrm{O}_{3}$ level was lower than that of Wariguan and Shangdianzi and close to the Jinsha background site $[53,54]$; the main reason for this is that Akedala and Jinsha are remote rural background sites, to which pollutant transport contributed equally, and Shangdianzi is located in an economically developed area of China, where industrial and vehicle emissions make an important contribution, whereas Wariguan is located on the Qinghai-Tibet plateau, which features high ozone levels associated with strong radiation. The highest hourly average of Akedala's CO concentration was below $700 \mathrm{ppb}$ and was at its highest level during the winter, with an average of $123.78 \pm 73.35 \mathrm{ppb}$ and a median of $102.75 \mathrm{ppb}$. Compared to other local stations, it was lower than the CO concentration level of the Lin'an $(372.5 \pm 0.6 \mathrm{ppb})$ [55] and Shangdianzi background stations (159.4 $\pm 0.4 \mathrm{ppb})[53]$ and was similar to Shangri-La and Wariguan in western China [56]. The main reason for this could be that the atmospheric $\mathrm{CO}$ at the eastern stations is primarily affected by the air masses emitted by nearby megacities and the monsoons, reflecting the impacts of man-made pollution. Shangri-La and Wariguan are representative of the $\mathrm{CO}$ background level of the Qinghai-Tibet Plateau. The air mass is blocked by the plateau's topography, and the long-distance airflow is relatively clean. The average value of $\mathrm{NO}_{2}$ was concentrated between 2 and $8 \mathrm{ppb}$ and was $3.79 \pm 0.98 \mathrm{ppb}$, whereas the maximum value was $11.13 \mathrm{ppb}$ and the median value $3.74 \mathrm{ppb}$ in Akedala, which is closer to the $\mathrm{NO}_{2}$ level at Longfeng Mountain [57]. The latter represents the agricultural area of the Northeast Great Plain, and Akedala the agricultural plain area of northern Xinjiang. Both can reflect the background of $\mathrm{NO}_{2}$ emissions from agricultural production, and the average value of the $\mathrm{SO}_{2}$ was also concentrated between 2 and $8 \mathrm{ppb}$, whereas the maximum was more than $16 \mathrm{ppb}$. The average value was $4.59 \pm 0.88 \mathrm{ppb}$ and the median was $4.37 \mathrm{ppb}$ in Akedala. The concentration of $\mathrm{SO}_{2}$ was high in the winter, affected by heating period in Xinjiang, and was significantly lower than that at Lin'an station [58] and Shangdianzi [59] and higher than that at Wariguan and Jinsha [60]. The main reason for this might depend on the difference in fuel burning sulfur emissions. 
As is shown in Figure 3, the monthly statistical results of the hourly average value of the reactive gases revealed that there were certain differences in the mixing ratio of each reactive gas from month to month. The mixing ratio of $\mathrm{O}_{3}$ in the autumn season was relatively low, and the minimum ozone value of Akedala occurred in December (18.50 ppb), whereas the maximum was measured in February (38.03 ppb). A decreasing trend was apparent from September to November (autumn). Meanwhile, the $\mathrm{O}_{3}$ mixing ratio in February (winter) showed an increasing trend, and March-May (spring) and June-August (summer) were at a higher level, which differed from those of other background stations in China, such as the $\mathrm{O}_{3}$ peak in Shangdianzi and Lin'an in the summer, driven by the Asian summer monsoon [61]. However, the Akedala background station was influenced by the westerly circulation, and there was a relatively strong stratospheric ozone intrusion from high latitudes [62]. The high value region of monthly $\mathrm{CO}$ variation in Akedala is concentrated in winter (December-February), and the maximum value appeared in February, which was 208.49 ppb, and slightly earlier than that at the northern hemisphere site [63]. Due to heating, the contribution of $\mathrm{CO}$ emission sources in winter is higher than in the other seasons. The winter spans December to February and is the main period for coal-fired heating. The incomplete combustion of coal is an important source of CO. The electricity and thermal energy produced by Central Asian countries such as Kazakhstan are mainly based on coal, and the high-emission $\mathrm{CO}$ in winter was also transported to the background station through the northwest airflow [64]. In November, the CO mixing ratio showed a slight upward trend, and that in the spring (March-May) showed a slight downward trend, with the minimum value appearing in August, at $72.52 \mathrm{ppb}$, in Akedala. Compared with other background stations, this emerging seasonal maximum and minimum was close to those in Lin'an and Longfengshan [65] but tended to differ from Shangdianzi [66] and was affected by emissions as well as special weather conditions (wind direction, wind speed, air quality transport). The distribution of $\mathrm{NO}_{2}$ mixing ratio showed a "fluctuation change" in autumn and winter. The $\mathrm{NO}_{2}$ concentration level in autumn was the highest, and there could be large nitrogen oxide emissions produced by biomass combustion in Akedala, as agricultural crop residues are burned not only as household fuel, but also directly in the fields, especially during the autumn harvest season, which may result in serious local and regional pollution [67]. $\mathrm{NO}_{2}$ mixing ratios exhibited a downward trend in the spring and summer from a monthly point of view, and the average $\mathrm{NO}_{2}$ value was the highest, at $4.51 \mathrm{ppb}$, in March, and lowest, at $2.28 \mathrm{ppb}$, in August. Construction resumed in the spring, machinery and vehicle use began to increase, and road traffic and agricultural activities emitted relatively more $\mathrm{NO}_{2}$. In Kazakhstan, $\mathrm{NO}_{2}$ emissions were fairly high in March, when coal-fired heating was still being supplied in power plants; $\mathrm{NO}_{2}$ in the atmosphere has a long lifespan. Cold air from Siberia moves eastward and transports $\mathrm{NO}_{2}$ southwards to the Akedala background station [68].
Compared with Akedala, Shangdianzi, Wariguan, and Longfengshan all showed high $\mathrm{NO}_{2}$ levels during winter and low $\mathrm{NO}_{2}$ in the summer [59]. This type of seasonal cycle can be explained as the higher heat supply leading to high $\mathrm{NO}_{2}$ emissions in winter, and stronger removal through photochemical conversion and wet deposition in the summer, with seasonal changes at the height of the mixed layer. The monthly mixing ratio of $\mathrm{SO}_{2}$ underwent little fluctuation. The $\mathrm{SO}_{2}$ level in the winter is relatively high and is similar in other seasons, reaching its maximum in January, which totaled $5.70 \mathrm{ppb}$ in Akedala. This is similar to that of Longfeng Mountain, which had higher levels of $\mathrm{SO}_{2}$ mixing ratio in the cold seasons [65]. Due to the influence of atmospheric diffusion conditions and seasonal changes in different regions, the month with the highest mixing ratio of Akedala, compared with that of Lin'an, and the highest $\mathrm{SO}_{2}$ mixing ratio at the Lin'an background station was December [69]. The reasons for the higher $\mathrm{SO}_{2}$ level in the winter were that coal-fired heating activities were more frequent, the removal of $\mathrm{SO}_{2}$ by chemical conversion and precipitation of quantity was minimal, and the winter has a lower boundary layer height, which is conducive to the accumulation of pollutants.

Figure 4 shows the average daily changes of $\mathrm{CO}, \mathrm{O}_{3}$, $\mathrm{NO}_{2}$, and $\mathrm{SO}_{2}$ mixing ratios in Akedala. In terms of $\mathrm{CO}$, the average mixing ratio was the highest in the winter and lowest in the summer. The average daily range across the four seasons (which refers to the difference between the maximum and minimum values) was distributed at 40.65, 130.86, 62.89 , and $51.99 \mathrm{ppb}$. The difference value was the largest in the winter because the winter photochemical reaction was weak, due to the heating and the burning of fossil fuels and biomass combustion, with relatively stable changes in the spring, summer, and autumn. The peak value reached around 13:00 during the four seasons, and the peak value in winter was the largest, at $285.95 \mathrm{ppb}$. The peak value in the autumn, spring, and summer was $129.20 \mathrm{ppb}, 122.09 \mathrm{ppb}$, and $100.06 \mathrm{ppb}$, respectively. The $\mathrm{CO}$ mixing ratio values of the four seasons all appeared at night, among which the minimum values of spring, summer, and autumn occurred at $03: 00$, and the minimum $\mathrm{CO}$ mixing ratio in winter at 01 : 00. For $\mathrm{O}_{3}$ in Akedala, the mixing ratio in the spring and summer was significantly higher than that in the autumn and winter, and the average daily range during the four seasons of autumn, winter, spring, and summer was 16.51, $12.25,20.32$, and $26.86 \mathrm{ppb}$. The peak mixing ratios were $33.96,33.31,44.05$, and $42.87 \mathrm{ppb}$, respectively. The daily range of $\mathrm{O}_{3}$ was the largest in the summer and the lowest in the winter. The reason for this was that solar radiation was strong in summer. The photochemical reaction was intense, the height of the mixed layer was high, the air within was well mixed and the abovementioned characteristics generated obvious differences during the day and night; the atmospheric conditions in winter contrasted with those in summer, the height of the mixed layer was low, the quiet and stable weather increased, and the air pollutants on the ground were not easily diffused, gathering on the surface and becoming coupled with low temperatures, solar radiation, 


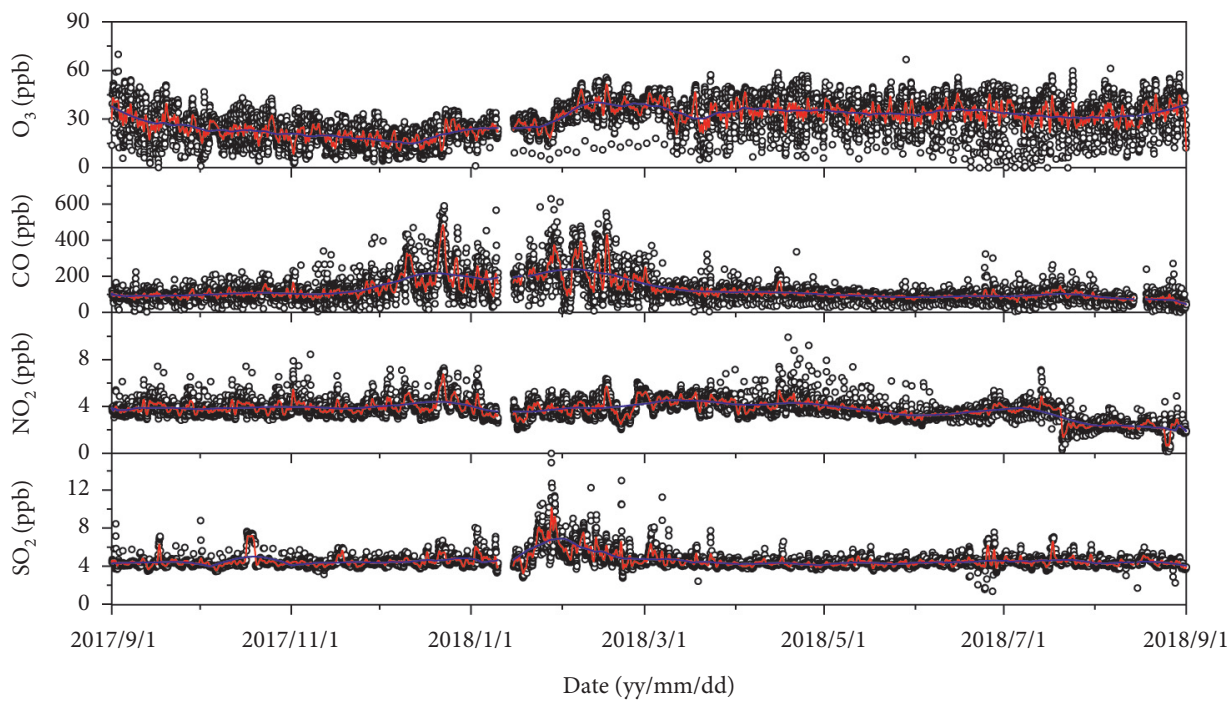

Figure 2: Time series changes in the hourly averages of $\mathrm{O}_{3}, \mathrm{CO}, \mathrm{NO}_{2}$, and $\mathrm{SO}_{2}$ on the ground during the observation period from September 2017 to August 2018. The black circle is the hourly average, the thin red line is the 24-hour smoothening, and the blue thick solid line is the 30-day smoothening.

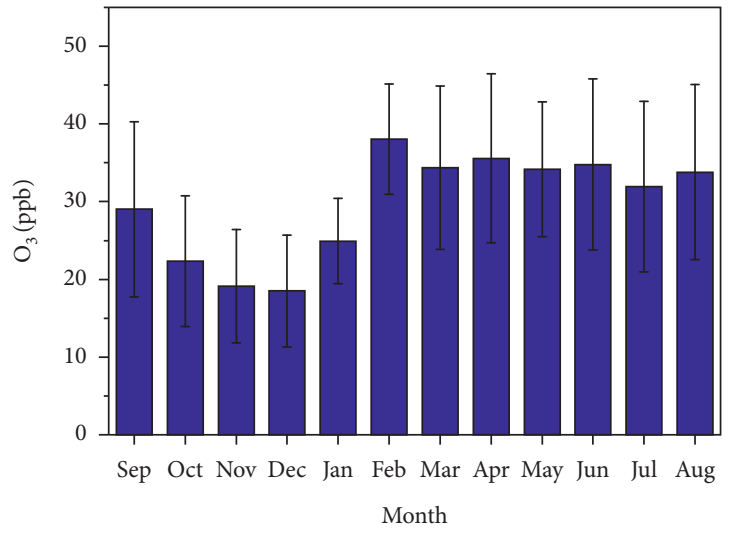

(a)

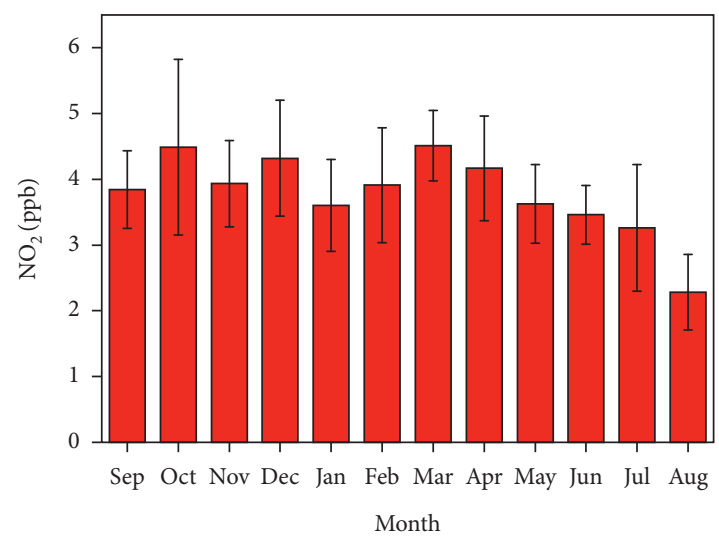

(c)

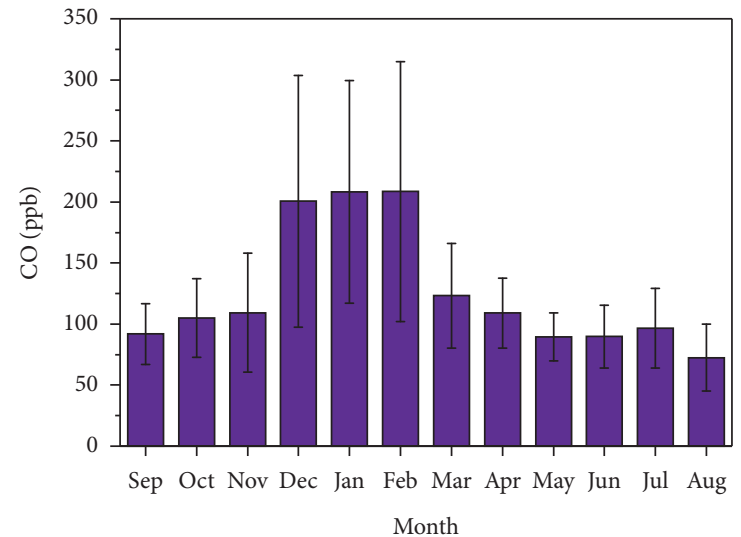

(b)

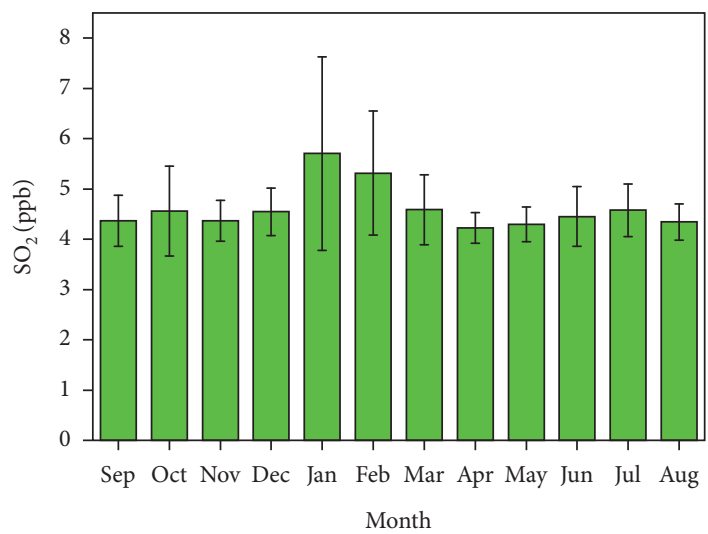

(d)

FIgURE 3: Monthly statistical results of the mean hourly mixing ratios of $\mathrm{O}_{3}, \mathrm{NO}_{2}, \mathrm{CO}$, and $\mathrm{SO}_{2}$.

and weak photochemical reactions in the winter [53]. Generally speaking, the $\mathrm{O}_{3}$ mixing ratio rises sharply at 8 : 00. The four seasons of the $\mathrm{O}_{3}$ peak all appeared at 16 :
00-18:00, when the ozone of the photochemical reaction had been accumulated, and then the solar radiation weakened and the $\mathrm{O}_{3}$ consumption predominated. The $\mathrm{O}_{3}$ mixing 


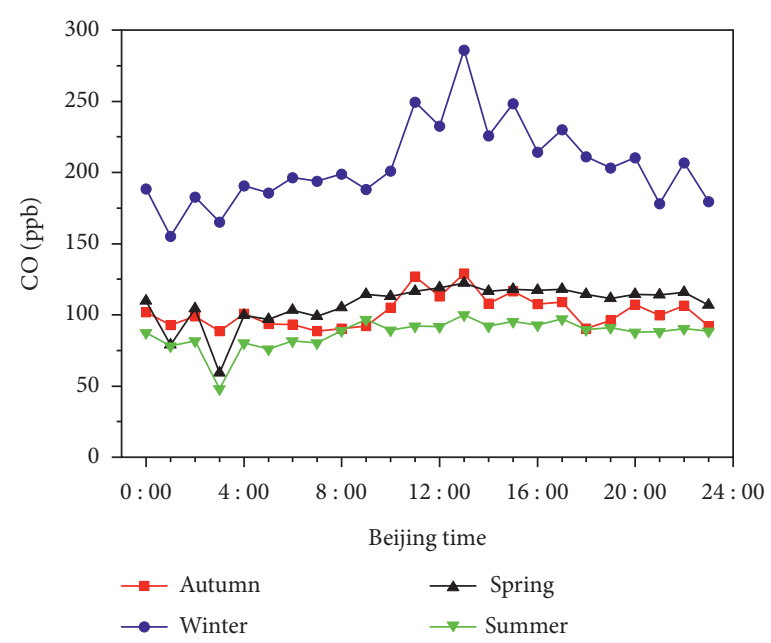

(a)

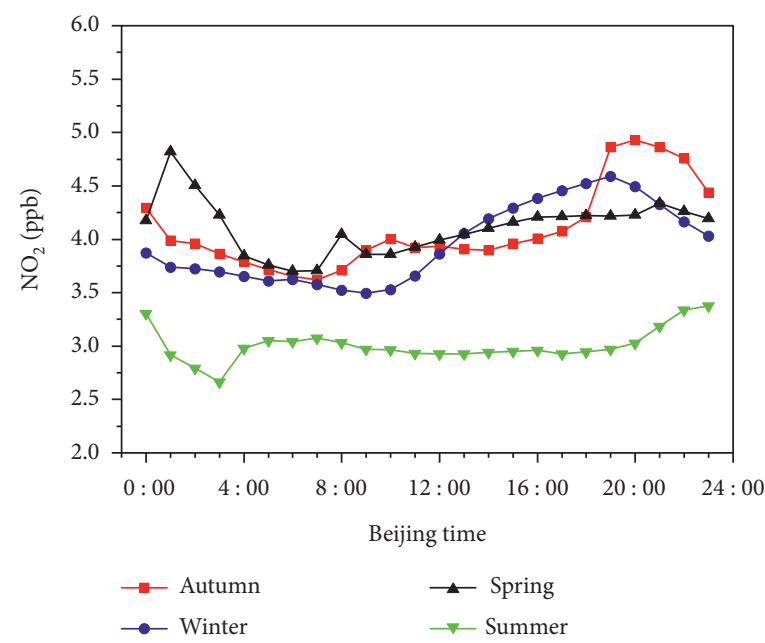

(c)

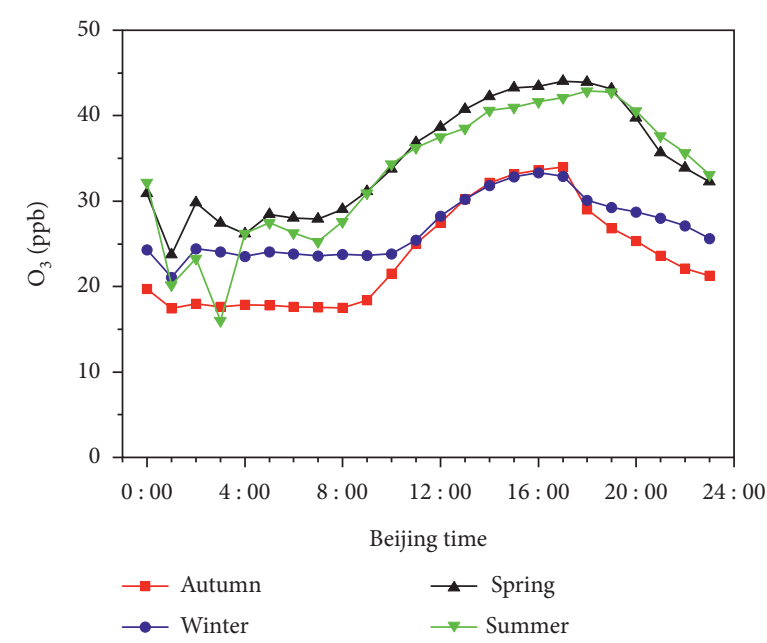

(b)

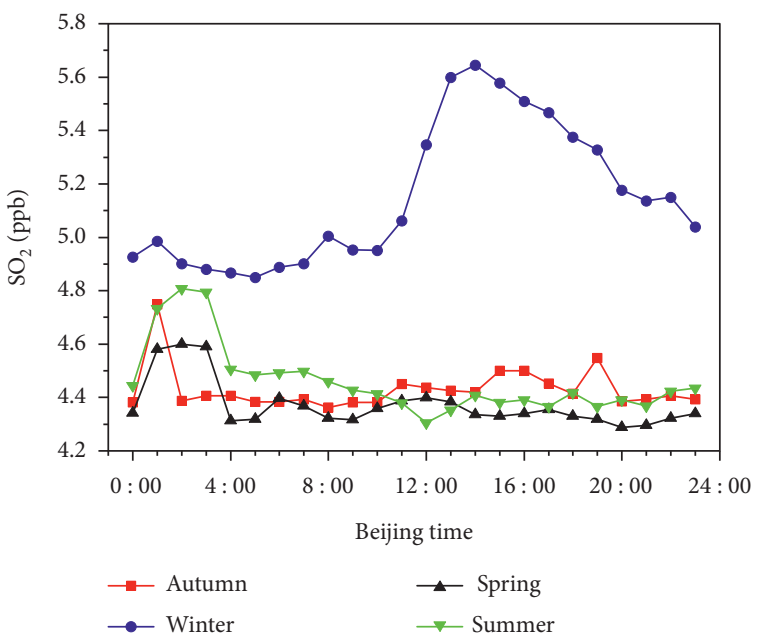

(d)

FIGURE 4: Average diurnal variations of reactive gases in different seasons at the Akedala background station from September 2017 to August 2018.

ratio gradually decreased, and the night level was the smallest, concentrated between $01: 00$ and 03:00 in Akedala. With respect to $\mathrm{NO}_{2}$, the $\mathrm{NO}_{2}$ mixing ratio level in summer was significantly lower than in the other seasons in Akedala; the average daily range in the four seasons of autumn, winter, spring, and summer was 1.31, 1.09, 1.11, and $0.71 \mathrm{ppb}$, respectively; and the daily variation was generally stable, with the high value periods being concentrated at about $20: 00,19: 00,1: 00$, and $23: 00$ in autumn, winter, spring, and summer and the peaks being $4.93 \mathrm{ppb}, 4.59 \mathrm{ppb}$, $4.82 \mathrm{ppb}$, and $3.37 \mathrm{ppb}$, respectively, indicating that both solar radiation and $\mathrm{NO}_{2}$ consumption decreased. With respect to $\mathrm{SO}_{2}$, the winter diurnal changes were more significant, and the mixing ratio level was high. $\mathrm{SO}_{2}$ is a primary pollutant and is especially affected by man-made and meteorological conditions. The atmospheric stratification temperature in the winter was prone to inversion, and $\mathrm{SO}_{2}$ easily accumulated [70]. Similar to $\mathrm{CO}, \mathrm{SO}_{2}$ fluctuated smoothly before $11: 00$, showing a significant upward trend at $12: 00-15: 00$ and reaching a peak at $15: 00,5.58 \mathrm{ppb}$, and then the average mixing ratio of $\mathrm{SO}_{2}$ exhibited a downward trend in Akedala. The low mixing ratio of $\mathrm{SO}_{2}$ at night could be due to the removal of the high humidity environment in the area at night during the winter. In the spring, summer, and autumn, the fluctuation is severe from 0:00 to 4:00 and reaches its maximum at night. The daily range of $\mathrm{SO}_{2}$ in the four seasons of autumn, winter, spring, and summer was $0.39,0.79,0.31$, and $0.50 \mathrm{ppb}$, respectively.

3.2. Identification of Local Sources. Wind field can affect the diffusion and the local and transboundary transportation of pollutants [71]. In general, wind speed has a considerable effect on pollutant transportation and removal [72, 73]. During environmental processes, the difference in wind direction reflects the path of pollutant transmission $[74,75]$.

Figure 5 shows the near-surface winds, and their effect on mixing ratios of reactive gases was analyzed using the hourly observation of reactive gases and wind data from September 2017 to August 2018. Figures 5(a)-5(d) clearly 


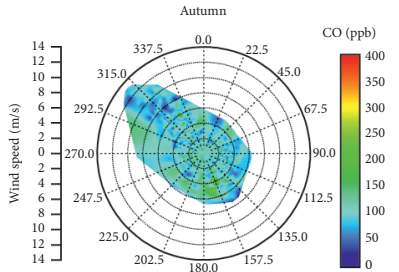

(a)

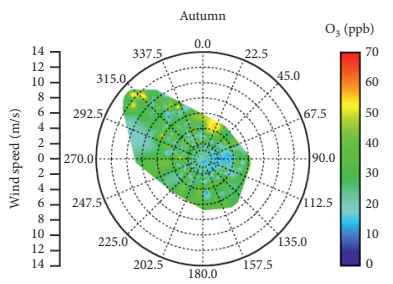

(e)

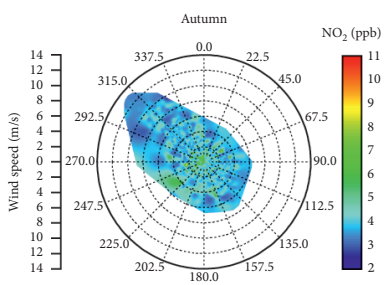

(i)

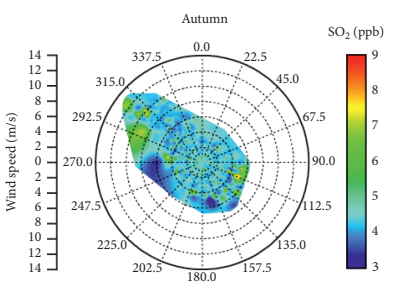

(m)

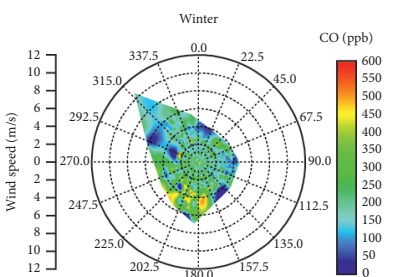

(b)

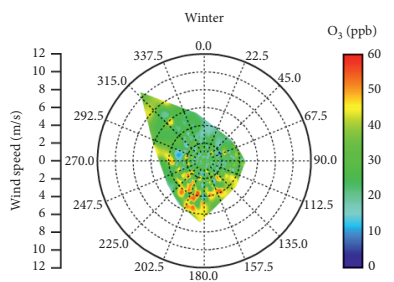

(f)

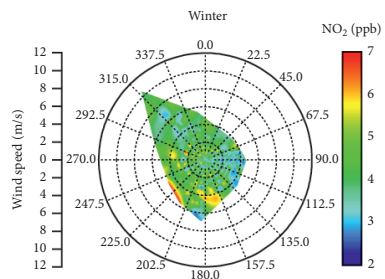

(j)

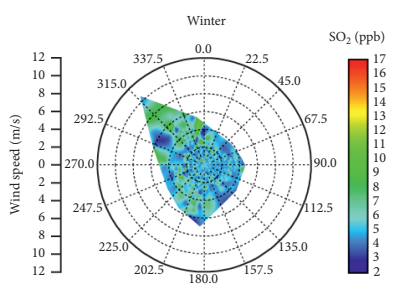

(n)

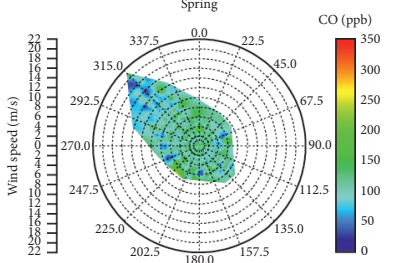

(c)

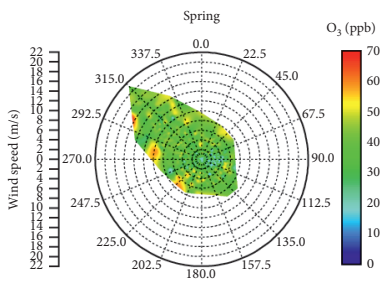

(g)

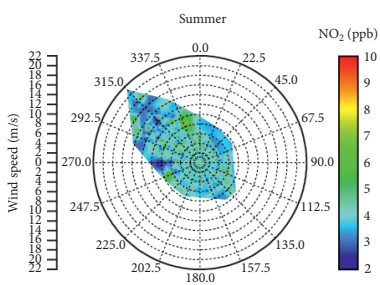

(k)

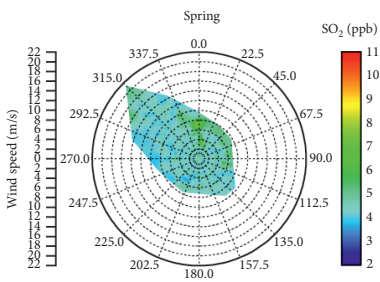

(o)

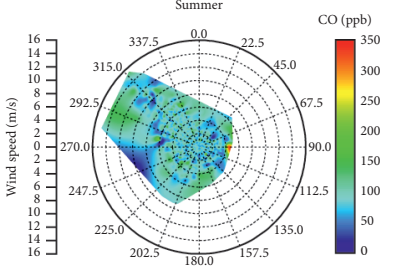

(d)

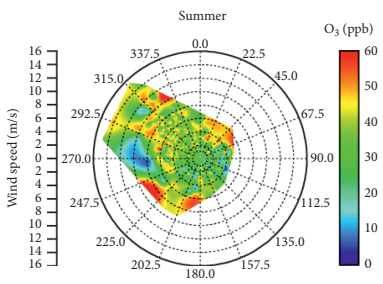

(h)

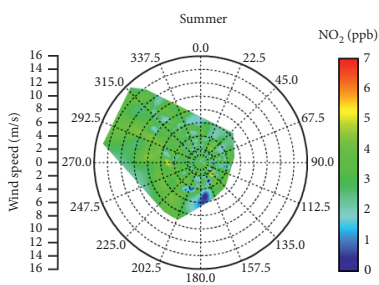

(1)

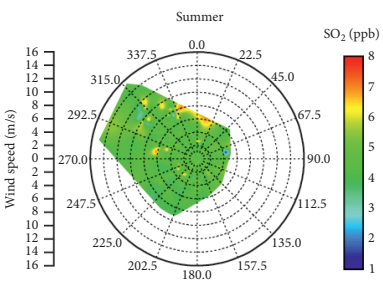

(p)

FIgURE 5: Wind roses with reactive gases $\left(\mathrm{CO}, \mathrm{O}_{3}, \mathrm{NO}_{2}\right.$, and $\left.\mathrm{SO}_{2}\right)$ mixing ratios in four seasons.

show that $\mathrm{CO}$ was highly influenced by wind direction in the winter. Winds from the southwest (SW), south-southwest (SSW), south (S), and south-southeast (SSE) corresponded to higher $\mathrm{CO}$ mixing ratios, which were above $400 \mathrm{ppb}$. The wind speeds in these sectors were close to $4-6 \mathrm{~m} / \mathrm{s}$, and their main sources might be heating and combustion activities in Fuhai County near the southwest of the background station and regional emissions from Karamay Oilfield [76, 77]. The corresponding $\mathrm{CO}$ mixing was relatively high, at 150-250 ppb, in the SSE and west-northwest (WNW) wind directions. In the WNW direction, the $\mathrm{CO}$ high mixing ratio appeared in the wind speed range of $4-6 \mathrm{~m} / \mathrm{s}$, while in the SSE direction, the $\mathrm{CO}$ high mixing ratio corresponded to a high wind speed (greater than $8 \mathrm{~m} / \mathrm{s}$ ). In spring, the $\mathrm{CO}$ mixing ratios corresponding to each sector had a small difference.

Figures 5(e)-5(h) show that when $\mathrm{O}_{3}$ corresponded to the WNW and east (E) directions in autumn, the airflow was relatively clean and the corresponding wind speeds were $10-12 \mathrm{~m} / \mathrm{s}$ and $2-4 \mathrm{~m} / \mathrm{s}$, respectively. The other directions had no significant influence on $\mathrm{O}_{3}$. The high $\mathrm{O}_{3}$ mixing ratio mainly appeared in the southern area of the background station in winter, which might came from the
"Urumqi-Changji-Shihezi" urban agglomeration on the southern margin of the Junggar Basin. The region was industrially well developed and produced high ozone precursors [45], which corresponded to the SW, SSW, S, SSE, and southeast (SE) sectors with $\mathrm{O}_{3}$ mixing ratio of more than $40 \mathrm{ppb}$. The high contribution areas of $\mathrm{O}_{3}$ sporadically appeared in the SW, west (W), and WNW wind directions during the spring, which corresponded to the $\mathrm{O}_{3}$ mixing ratio of $50-60 \mathrm{ppb}$. In the northwest (NW), SW, and northeast (NE) directions, the mixing ratios of $\mathrm{O}_{3}$ had a significant increase in summer, which was above $50 \mathrm{ppb}$. The wind speed ranges corresponding to $\mathrm{O}_{3}$ high values in the above three directions were $6-10,8-14$, and $4-6 \mathrm{~m} / \mathrm{s}$, respectively.

Figures 5(i)-5(l) show that $\mathrm{NO}_{2}$ was not significantly affected by wind direction in spring, summer, and autumn. The mixing ratio of $\mathrm{NO}_{2}$ corresponding to each wind direction was concentrated at $3-5 \mathrm{ppb}$. The S, SW, and $\mathrm{W}$ wind directions corresponded to a higher mixing ratio of $\mathrm{NO}_{2}$ (5-7 ppb), and wind speed ranges from 4 to $6 \mathrm{~m} / \mathrm{s}$ in winter, which might be mainly contributed by frequent traffic activities in the north of Tianshan Mountain [78, 79]. 
Figures $5(\mathrm{~m})-5(\mathrm{p})$ show that the wind directions of WNW, NW, and east-southeast (ESE) significantly uplifted the $\mathrm{SO}_{2}$ mixing ratio in autumn, and the corresponding $\mathrm{SO}_{2}$ value was $6-7 \mathrm{ppb}$. The wind speed ranges of the three high value areas were $8-10,10-12$, and $4-6 \mathrm{~m} / \mathrm{s}$, respectively. The high value areas of $\mathrm{SO}_{2}$ appeared in the $\mathrm{NW}$ and $\mathrm{S}$ of the background station in winter. These two wind directions had high $\mathrm{SO}_{2}$ mixing ratios, concentrated at $7-13 \mathrm{ppb}$, and their corresponding wind speeds were $6-10$ and $4-6 \mathrm{~m} / \mathrm{s}$, respectively. The $\mathrm{SO}_{2}$ mixing ratios in the northwest might be derived from the contribution of long-range transport air masses, for example, in Kazakhstan. The high $\mathrm{SO}_{2}$ mixing ratio in the south of the background station might came from the local transportation of Urumqi in the southern margin of the basin, where the demand and consumption rate of fossil fuels were high in winter, and a large amount of $\mathrm{SO}_{2}$ was emitted by human activities [80]. The north $(\mathrm{N})$, $\mathrm{NE}$, and $\mathrm{E}$ directions had a slight lifting effect on the $\mathrm{SO}_{2}$ mixing ratios in spring. The high value was concentrated at $6-8 \mathrm{ppb}$, corresponding to the wind speed range of $6-8 \mathrm{~m} / \mathrm{s}$, while those in other directions were concentrated at $4-5 \mathrm{ppb}$. The effect of wind direction on $\mathrm{SO}_{2}$ mixing ratio was not significant in summer, and the high value areas had a pointed shape with corresponding mixing ratios of 6-8 ppb.

3.3. Cluster Analyses. Akedala is a low-altitude environmental background area in northwestern China and is more sensitive to regional environmental changes. The average value of reactive gases corresponding to various airflow trajectories had significant differences (see Figures 6 and 7 and Table 2). The trajectory clustering calculation was undertaken by adding the hourly average data of reactive gases to the backward trajectory and then dividing the seasonal airflow trajectories of Akedala into six categories in accordance with the total spatial variance method. Based on the results of the cluster analysis of the airflow trajectories in each season, the cluster statistics module was used to analyze the average value of reactive gases corresponding to different types of trajectory (Table 2) in order to quantitatively characterize the mixing ratio level characteristics of reactive gases under the influence of different types of flow trajectory.

In autumn, the frequency of various trajectories was as follows: $4>2>5>1>6>3$ (Figure 6). The airflow trajectories $(2,4,5)$ from the northwest of Kazakhstan accounted for $74.54 \%$ of the total trajectories, which was the most significant airflow direction that affected the Akedala background station in autumn, and this type of airflow trajectory was primarily affected by the westerly circulation system [81]. Trajectory 2 derived from Balkhash Lake in Kazakhstan; passed through the northern border of Xinjiang, China; and then extended to the northeast, finally moving east from the Irtysh River Valley to Akedala. Trajectory 4 originated in northeastern Kazakhstan, passing through the Kazakh Uplands and Zaysan Lake and progressing downstream of the Irtysh River in Kazakhstan and finally to northern Xinjiang. Track 4 corresponded to the highest average value of $\mathrm{O}_{3}$, of $24.84 \pm 10.70 \mathrm{ppb}$. There are vast agricultural planting areas in eastern Kazakhstan and northern Xinjiang, which also coincide with the autumn harvest. The contribution of autumn straw burning in these areas cannot be ignored [82]. Trajectory 5 originated from the Tacheng area in Xinjiang and passed through the Tacheng air opening area and on to the Junggar Basin. When the pollutants in the Tacheng area were affected by the narrow tube and landslide effects, the airflow was easily accelerated. The first type of trajectory mainly originated from the Gurbantunggut Desert in northern Xinjiang. The average $\mathrm{CO}$ mixing ratio corresponding to this type of airflow was the highest, at $105.13 \pm 37.31 \mathrm{ppb}$. The desert is strewn with oilfield operation areas, and crude oil extraction processes such as seismic drilling and steam soaking would release toxic gases such as CO [83]. Trajectory 3 originated in Southern Russia, crossed the Altai Mountains, and entered Akedala from the southeast through Xinjiang. The sixth type of trajectory primarily originated in the Zhundong area of Xinjiang, where large coal fields were distributed, and the corresponding $\mathrm{NO}_{2}$ and $\mathrm{SO}_{2}$ of this type of airflow were the highest, at $4.42 \pm 1.41$ and $5.02 \pm 1.22 \mathrm{ppb}$, respectively. These two pollutants were affected by the emission of mining activities, mainly from mobile sources, fixed sources, and scattered sources. Mobile sources include vehicle transportation and excavating equipment, whereas fixed sources include large-scale operations such as drying, roasting, and smelting; dissipation sources mainly comprised plumes produced by open blasting [84].

In winter, the occurrence frequency of various kinds of tracks from high to low was as follows: $2>5>6>1>3>4$. Mongolia's high pressure constitutes a weather system that significantly affects Xinjiang. The region was affected by the Xinjiang high-pressure ridge and East Asian trough, and cold air moved southward [85]. The second and fifth types of airflow trajectories from Kazakhstan in the winter accounted for the highest proportion, totaling 44.03\%. Among these, trajectory 5 in the winter was similar to trajectory 4 in the autumn, which originated in the eastern Kazakh city of Oskemen. Nonferrous metal smelting in this area is relatively developed, and the production process could emit more gaseous pollutants [86]. The second type of airflow trajectory originated in the east of Balkhash Lake and Tacheng City, crossing the Saur Mountains, with the average value of $\mathrm{O}_{3}, \mathrm{CO}$, and $\mathrm{NO}_{2}$ corresponding to this type of airflow trajectory being the highest, at $31.24 \pm 11.90$, $251.72 \pm 122.13$, and $4.26 \pm 1.11 \mathrm{ppb}$, respectively; the main polluted area in this trajectory was Tacheng City, which was mainly influenced by coal-fired heating in the winter. Trajectories 1 and 6 originated from the border areas of Mongolia, accounting for $35.46 \%$ of the total trajectories. The highest $\mathrm{SO}_{2}$ average value corresponding to the airflow trajectory was $5.63 \pm 2.00 \mathrm{ppb}$. Western Mongolia is dominated by agriculture and animal husbandry, and the family lifestyle is relatively undeveloped, which is likely to result in the emission of pollutants. Due to the increase in heating demand in winter, a large amount of coal and wood would be consumed. According to the statistics, each family in Mongolia used about 5.0 tons of coal and three cubic meters of wood per year for heating and cooking purposes [87]. Trajectory 3 passed through the Karamay Tuyere, which is 


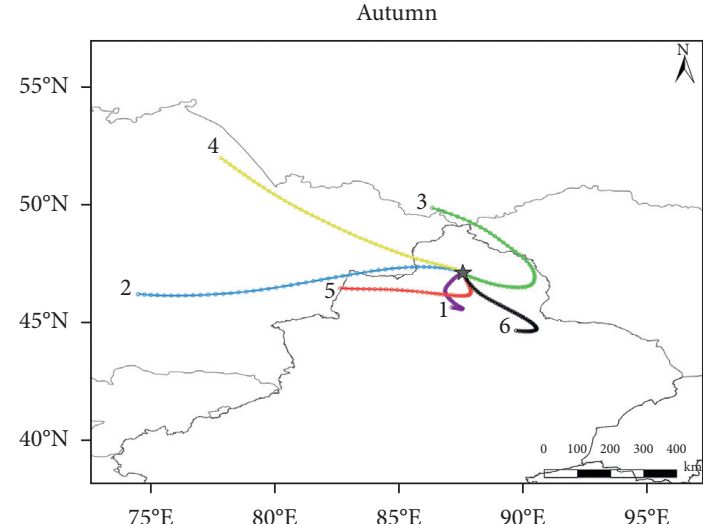

(a)

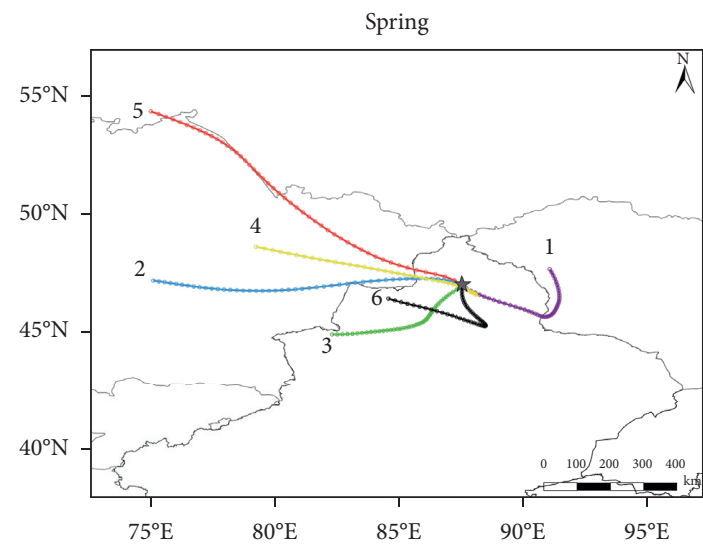

(c)

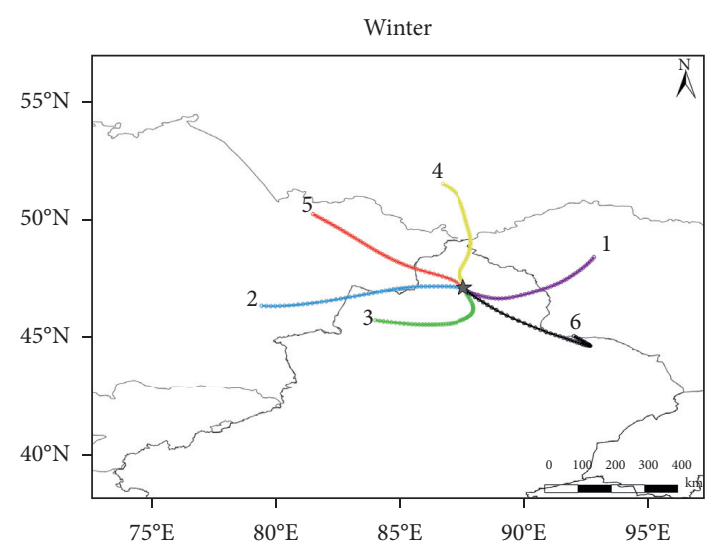

(b)

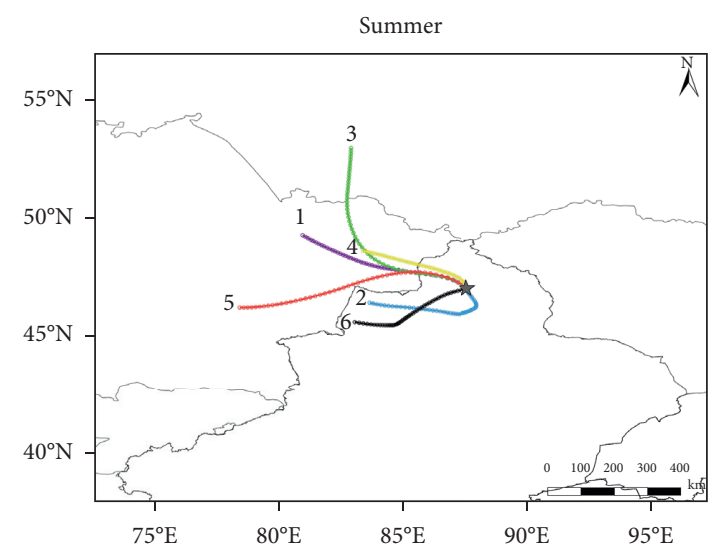

(d)

Figure 6: Seasonal distribution of the back trajectories clusters in Akedala from September 2017 to August 2018.

located to the west of Baikouquan, in Urho. The unique topography and the effect of cold air crossing the mountains and depressions could easily cause strong winds and carry pollutants.

In the spring, the frequency of various trajectories from high to low was as follows: $2>5>4>3>6>1$. This season was mainly affected by the eastward movement of cold air from Siberia to the south, and the airflow trajectory from Kazakhstan and northwest of the Russian border $(2,4,5)$ accounted for the largest proportion, totaling $73.78 \%$. Track 2 originated to the north of Balkhash Lake and then progressed along the northern border of Xinjiang. This type of airflow trajectory corresponded to the highest $\mathrm{NO}_{2}$ mixing ratio, which was $4.25 \pm 0.79 \mathrm{ppb}$. Fishing activities around Lake Balkhash are relatively developed and ship exhaust gas emissions cannot be ignored [88] $\mathrm{NO}_{2}$ would be emitted from the agriculture and animal husbandry developed in northern Xinjiang, including nitrogen fertilizer applications in the spring, accumulation of animal manure, and exhaust emissions from transportation equipment [89]. Trajectory 5 originated in Russia, passed through the Pavlodar region, and then entered Akedala from the Irtysh Valley in China. This type of trajectory corresponded to the highest $\mathrm{O}_{3}$ mixing ratio, which was $36.25 \pm 7.59 \mathrm{ppb}$. The Pavlodar region is a major industrial center; is engaged in the following industrial activities: bauxite mining, alumina and aluminum production, thermal power production, oil refining, and mechanical engineering; and might produce greater ozone pollutants [90]. Track 4 originated in the eastern Kazakhstan Region and then entered Akedala through Jeminay County and the Wulungu River. Eastern Kazakhstan is rich in minerals. The metallurgical industry is the pillar industry in the area, and industrial furnaces are used to add fuel. During smelting, a large amount of harmful waste gases such as CO is produced [91]. The first type of airflow trajectory originated in the west of Mongolia, crossing the Altai Mountains and moving northwestward to Akedala. The third type of airflow trajectory originated from the Alataw Pass. This airflow then easily moved eastward, passing through Karamay, and was transported to the background station. Trajectory 6 originated from the Tacheng area. The westerly airflow had a convergence effect and was transported to the southeast through the Karamay Oilfield. Oilfield extraction, refining, and processing would release a large amount of $\mathrm{SO}_{2}$ [76]. The average $\mathrm{SO}_{2}$ value corresponding to this trajectory was $4.44 \pm 0.77 \mathrm{ppb}$.

In the summer, the frequency of occurrence of the various airflow trajectories was as follows: $1>5>3>4>6>2$. The airflow trajectory was relatively concentrated, and the northwest and westerly winds prevailed in the summer. The frequency occupied by 1, 4, and 5 was, at most, $74.05 \%$. Both 1 and 4 originated in 


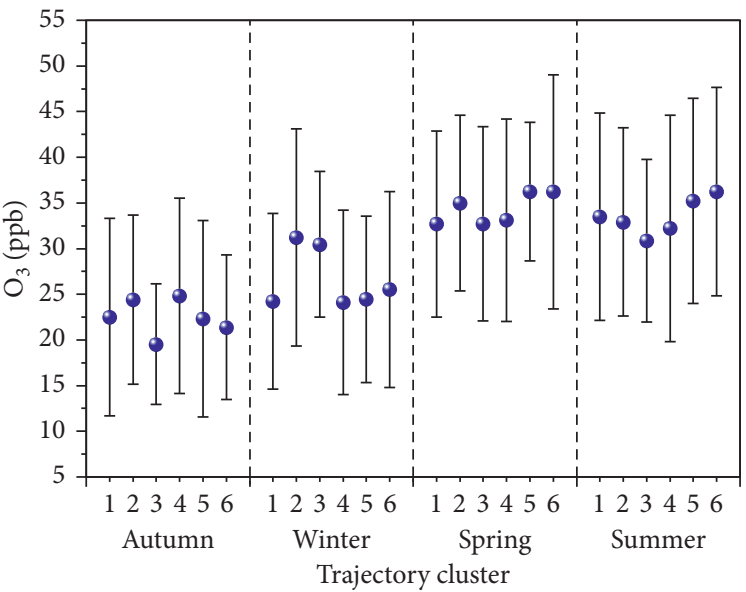

(a)

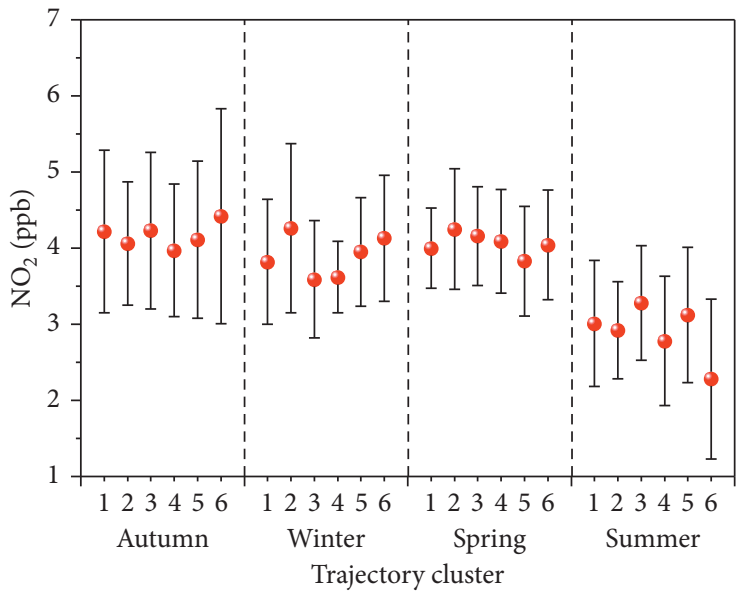

(c)

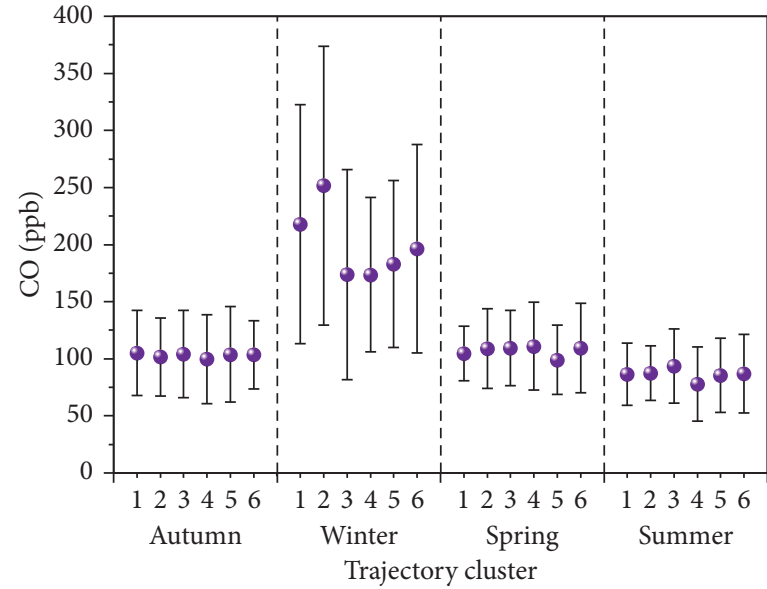

(b)

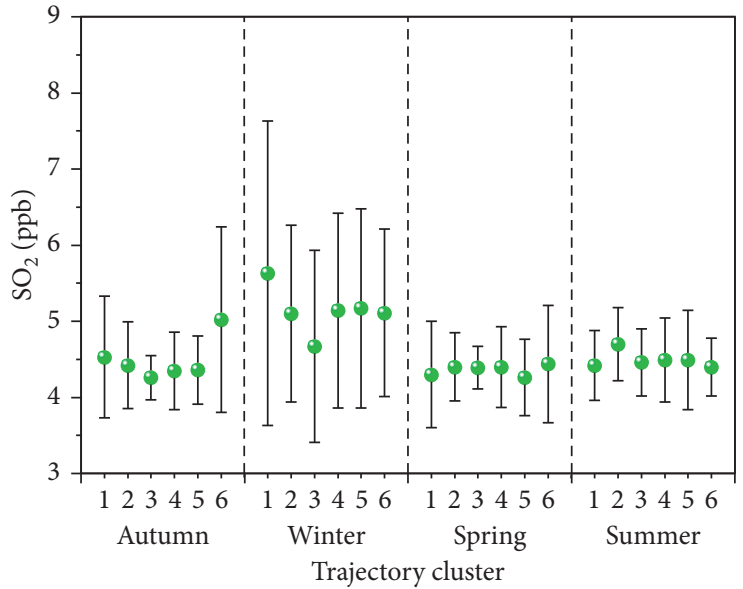

(d)

Figure 7: Average mixing ratios $\left(\mathrm{O}_{3}, \mathrm{CO}, \mathrm{NO}_{2}\right.$, and $\left.\mathrm{SO}_{2}\right)$ associated with the six trajectory clusters on a seasonal basis. The solid circle indicates the arithmetic mean, and the line is the standard deviation.

eastern Kazakhstan. Trajectories 1 and 4 started at Zaysan Lake, passed through cities around the Irtysh Valley such as those in Habahe and Burqin counties, and entered the background station. Trajectory 5 started from Balkhash Lake, moved eastward to Zaysan Lake, and then entered Xinjiang. Trajectories 2 and 6 mainly originated from cities in northern Xinjiang. Trajectory 2 started in Tacheng City and entered the northern part of the Junggar Basin. The maximum average $\mathrm{SO}_{2}$ value corresponding to track 2 was $4.70 \pm 0.48 \mathrm{ppb}$. There are many oil and gas fields in the northern area of the Junggar Basin. Drilling, production, and exhaust gas combustion are important sources of $\mathrm{SO}_{2}$ [92]. Trajectory 6 started at the Alataw Pass, moved east to Karamay, and was then transported in a northeastern direction to Akedala. The average $\mathrm{O}_{3}$ value corresponding to this type of airflow trajectory was the highest, at $36.23 \pm 11.42 \mathrm{ppb}$. Karamay Oilfield is an important petrochemical center in western China, producing petrochemicals, and petroleum transportation vehicles would emit a large amount of ozone precursors (VOC and NO $x$ ), which is conducive to the generation of ozone in the area [93]. Track 3 originated in Russia's Altai borders.
After passing through the Oskemen, the capital of East Kazakhstan, and then entering the background station along the Irtysh River Valley, the average mixing ratio of $\mathrm{CO}$ and $\mathrm{NO}_{2}$ corresponding to this type of airflow trajectory was the highest, at $93.67 \pm 32.54$ and $3.28 \pm 0.75 \mathrm{ppb}$, respectively. Oskemen in Kazakhstan has one of the country's worst air qualities. It is an important railway hub and river port, as well as a nonferrous metal smelting industrial center. Its nitrogen oxide and carbon monoxide emissions are primarily affected by road and industrial sources [64].

3.4. PSCF and CWT Analyses. Trajectory clustering analysis can be utilized to judge the main migration path of pollutants in the Akedala background station, but the relative contribution level of the potential source area around the reactive gas cannot be identified [32]. As is shown in Figure 8, using WPSCF to analyze the potential source distribution of reactive gas, red could relate to high mixing ratios of reactive gas, whereas blue reflects low mixing ratios in the source area. In order to better describe the distribution 
TABLE 2: Seasonal statistical analysis results of various trajectories in Akedala.

\begin{tabular}{|c|c|c|c|c|c|c|c|}
\hline Season & Clusters & $\begin{array}{l}\text { The number } \\
\text { of all } \\
\text { trajectories }\end{array}$ & $\begin{array}{l}\text { The percentage } \\
\text { of all } \\
\text { trajectories (\%) }\end{array}$ & $\begin{array}{c}\text { Mean mixing ratios } \\
\text { and standard } \\
\text { deviation of } \mathrm{O}_{3} \\
(\mathrm{ppb})\end{array}$ & $\begin{array}{l}\text { Mean mixing ratios } \\
\text { and standard } \\
\text { deviation of } \mathrm{CO}(\mathrm{ppb})\end{array}$ & $\begin{array}{l}\text { Mean mixing } \\
\text { ratios and } \\
\text { standard deviation } \\
\text { of } \mathrm{NO}_{2}(\mathrm{ppb})\end{array}$ & $\begin{array}{l}\text { Mean mixing } \\
\text { ratios and } \\
\text { standard } \\
\text { deviation of } \mathrm{SO}_{2} \\
(\mathrm{ppb})\end{array}$ \\
\hline \multirow{6}{*}{ Autumn } & 1 & 213 & 9.75 & $22.51 \pm 10.79$ & $105.13 \pm 37.31$ & $4.22 \pm 1.07$ & $4.53 \pm 0.80$ \\
\hline & 2 & 546 & 25 & $24.41 \pm 9.26$ & $101.73 \pm 34.15$ & $4.06 \pm 0.81$ & $4.42 \pm 0.57$ \\
\hline & 3 & 171 & 7.83 & $19.54 \pm 6.60$ & $104.40 \pm 38.23$ & $4.23 \pm 1.03$ & $4.26 \pm 0.29$ \\
\hline & 4 & 787 & 36.03 & $24.84 \pm 10.70$ & $99.72 \pm 38.86$ & $3.97 \pm 0.87$ & $4.35 \pm 0.51$ \\
\hline & 5 & 295 & 13.51 & $22.30 \pm 10.75$ & $103.87 \pm 41.84$ & $4.11 \pm 1.03$ & $4.36 \pm 0.45$ \\
\hline & 6 & 172 & 7.88 & $21.39 \pm 7.91$ & $101.97 \pm 37.33$ & $4.42 \pm 1.41$ & $5.02 \pm 1.22$ \\
\hline \multirow{6}{*}{ Winter } & 1 & 342 & 15.83 & $24.24 \pm 9.61$ & $217.89 \pm 104.70$ & $3.82 \pm 0.82$ & $5.63 \pm 2.00$ \\
\hline & 2 & 522 & 24.17 & $31.24 \pm 11.90$ & $251.72 \pm 122.13$ & $4.26 \pm 1.11$ & $5.10 \pm 1.16$ \\
\hline & 3 & 293 & 13.56 & $30.47 \pm 7.99$ & $173.72 \pm 92.04$ & $3.59 \pm 0.77$ & $4.67 \pm 1.26$ \\
\hline & 4 & 150 & 6.94 & $24.11 \pm 10.09$ & $173.65 \pm 67.73$ & $3.62 \pm 0.47$ & $5.14 \pm 1.28$ \\
\hline & 5 & 429 & 19.86 & $24.46 \pm 9.12$ & $183.06 \pm 73.33$ & $3.95 \pm 0.71$ & $5.17 \pm 1.31$ \\
\hline & 6 & 424 & 19.63 & $25.52 \pm 10.75$ & $196.41 \pm 91.10$ & $4.13 \pm 0.83$ & $5.11 \pm 1.10$ \\
\hline \multirow{6}{*}{ Spring } & 1 & 71 & 3.22 & $32.70 \pm 10.19$ & $104.54 \pm 23.80$ & $4.00 \pm 0.53$ & $4.30 \pm 0.70$ \\
\hline & 2 & 860 & 38.95 & $34.98 \pm 9.61$ & $109.00 \pm 35.03$ & $4.25 \pm 0.79$ & $4.40 \pm 0.45$ \\
\hline & 3 & 298 & 13.50 & $32.72 \pm 10.65$ & $109.36 \pm 32.87$ & $4.16 \pm 0.65$ & $4.39 \pm 0.28$ \\
\hline & 4 & 329 & 14.90 & $33.12 \pm 11.07$ & $110.98 \pm 38.44$ & $4.09 \pm 0.68$ & $4.40 \pm 0.53$ \\
\hline & 5 & 440 & 19.93 & $36.25 \pm 7.59$ & $99.14 \pm 30.21$ & $3.83 \pm 0.72$ & $4.26 \pm 0.50$ \\
\hline & 6 & 210 & 9.51 & $36.22 \pm 12.82$ & $109.43 \pm 39.14$ & $4.04 \pm 0.72$ & $4.44 \pm 0.77$ \\
\hline \multirow{6}{*}{ Summer } & 1 & 942 & 42.66 & $33.50 \pm 11.36$ & $86.66 \pm 27.26$ & $3.01 \pm 0.83$ & $4.42 \pm 0.46$ \\
\hline & 2 & 94 & 4.26 & $32.92 \pm 10.31$ & $87.46 \pm 23.92$ & $2.92 \pm 0.64$ & $4.70 \pm 0.48$ \\
\hline & 3 & 348 & 15.76 & $30.85 \pm 8.90$ & $93.67 \pm 32.54$ & $3.28 \pm 0.75$ & $4.46 \pm 0.44$ \\
\hline & 4 & 210 & 9.51 & $32.23 \pm 12.40$ & $77.96 \pm 32.59$ & $2.78 \pm 0.85$ & $4.49 \pm 0.55$ \\
\hline & 5 & 483 & 21.88 & $35.22 \pm 11.23$ & $85.63 \pm 32.61$ & $3.12 \pm 0.89$ & $4.49 \pm 0.65$ \\
\hline & 6 & 131 & 5.93 & $36.23 \pm 11.42$ & $86.83 \pm 34.41$ & $2.28 \pm 1.05$ & $4.40 \pm 0.38$ \\
\hline
\end{tabular}

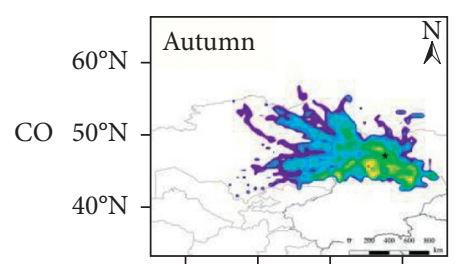

$60^{\circ} \mathrm{E} \quad 70^{\circ} \mathrm{E} \quad 80^{\circ} \mathrm{E} \quad 90^{\circ} \mathrm{E}$

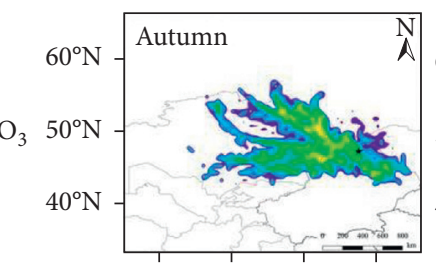

$60^{\circ} \mathrm{E} \quad 70^{\circ} \mathrm{E} \quad 80^{\circ} \mathrm{E} \quad 90^{\circ} \mathrm{E}$

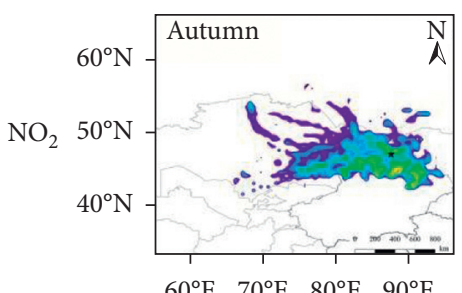

$60^{\circ} \mathrm{E} \quad 70^{\circ} \mathrm{E} \quad 80^{\circ} \mathrm{E} \quad 90^{\circ} \mathrm{E}$

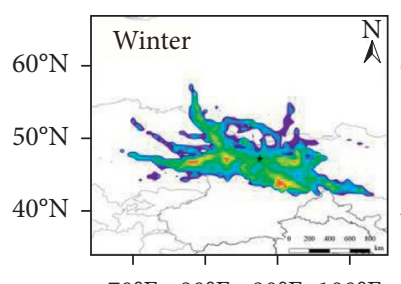

$70^{\circ} \mathrm{E} \quad 80^{\circ} \mathrm{E} \quad 90^{\circ} \mathrm{E} \quad 100^{\circ} \mathrm{E}$

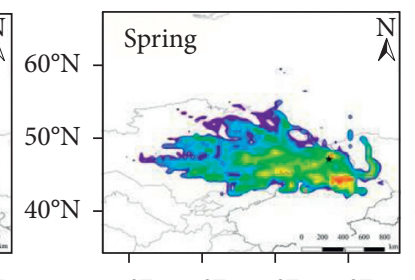

$60^{\circ} \mathrm{E} \quad 70^{\circ} \mathrm{E} \quad 80^{\circ} \mathrm{E} \quad 90^{\circ} \mathrm{E}$

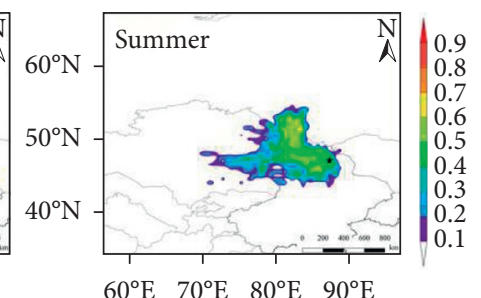

$60^{\circ} \mathrm{E} \quad 70^{\circ} \mathrm{E} \quad 80^{\circ} \mathrm{E} \quad 90^{\circ} \mathrm{E}$

(a)

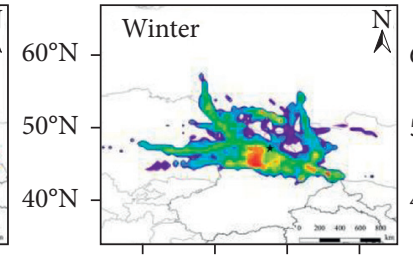

$70^{\circ} \mathrm{E} \quad 80^{\circ} \mathrm{E} \quad 90^{\circ} \mathrm{E} \quad 100^{\circ} \mathrm{E}$

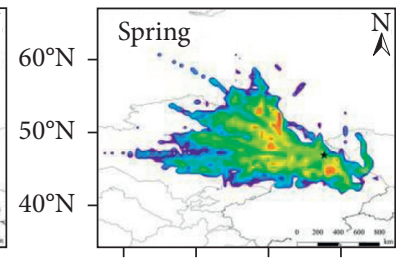

$60^{\circ} \mathrm{E} \quad 70^{\circ} \mathrm{E} \quad 80^{\circ} \mathrm{E} \quad 90^{\circ} \mathrm{E}$

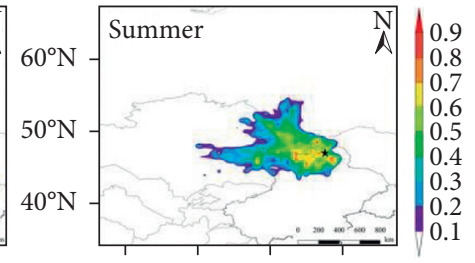

$60^{\circ} \mathrm{E} \quad 70^{\circ} \mathrm{E} \quad 80^{\circ} \mathrm{E} \quad 90^{\circ} \mathrm{E}$

(b)

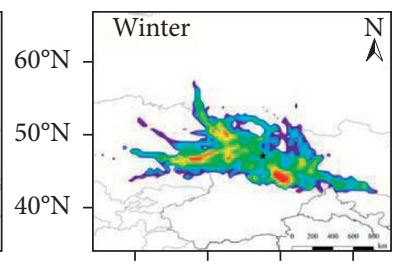

$70^{\circ} \mathrm{E} \quad 80^{\circ} \mathrm{E} \quad 90^{\circ} \mathrm{E} \quad 100^{\circ} \mathrm{E}$

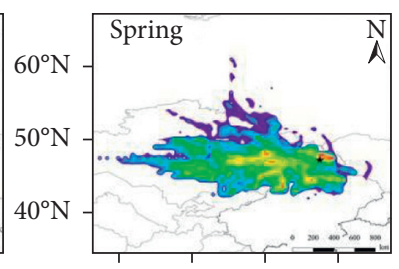

$60^{\circ} \mathrm{E} \quad 70^{\circ} \mathrm{E} \quad 80^{\circ} \mathrm{E} \quad 90^{\circ} \mathrm{E}$

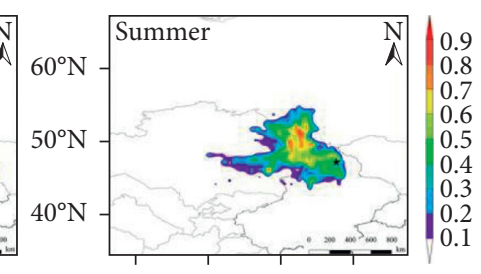

$60^{\circ} \mathrm{E} \quad 70^{\circ} \mathrm{E} \quad 80^{\circ} \mathrm{E} \quad 90^{\circ} \mathrm{E}$

(c)

Figure 8: Continued. 


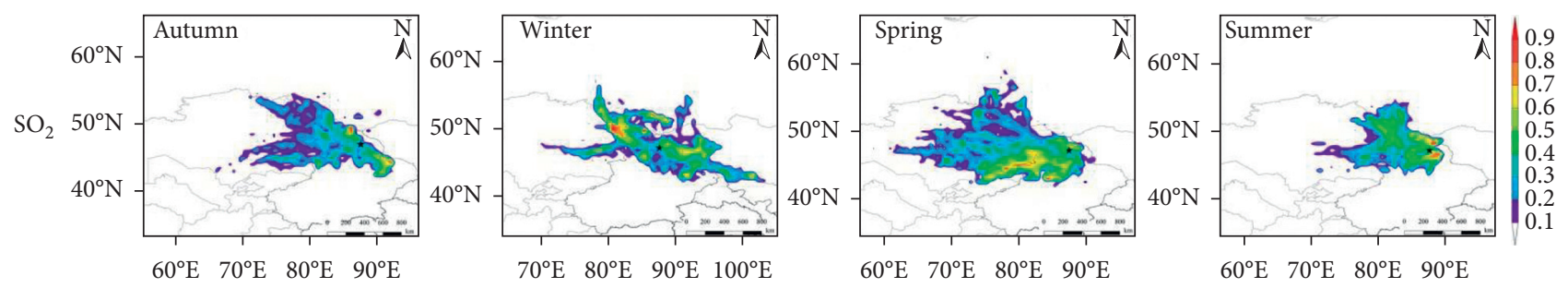

(d)

Figure 8: Seasonal distribution of the weighted potential source contribution function (WPSCF) of reactive gases in Akedala, from September 1, 2017, to August 31, 2018. The black star represents Akedala station.

of potential sources of reactive gases, the grids are divided into light, moderate, and heavy pollution zones, and the corresponding WPSCF values of each were $0-0.3,0.3-0.7$, and $0.7-1.0$, respectively.

In general, the potential source area of the reactive gas had a large spatial distribution, and the contribution level of reactive gas in the potential source area also had a certain difference across the different seasons. In terms of $\mathrm{CO}$, the potential sources of $\mathrm{CO}$ were concentrated in northern Xinjiang, and its WPSCF values were between 0.4 and 0.7 in the autumn. The main potential sources of $\mathrm{CO}$ indicated four major strip regions in the winter. The first is the Turpan Basin, where oilfield operations are located [94]. The second largest area originated around Lake Balkhash, affected by the cold air, and pollutants flowed eastward through the tuyere [95]. The third area was the Siberian Plain in Russia, and the fourth was mainly located in Western Mongolia. Its WPSCF value was between 0.5 and 0.8 . The main potential source of $\mathrm{CO}$ in the area is around the Junggar Basin, and this is affected by the westward airflow outside the country in spring. The WPSCF's high value areas appear in the eastern and southern regions of Kazakhstan. The potential source of CO primarily originated in the Altai border region of Russia and then entered Xinjiang through a large agricultural area in central East Kazakhstan in the summer [96]. The WPSCF value of the $\mathrm{O}_{3}$ was concentrated in 0.4-0.6. For $\mathrm{O}_{3}$, the main potential source areas were certain parts of Kazakhstan in the autumn, such as the area around Balkhash Lake and the cities along the Irtysh River. The value was between 0.6 and 0.7 . The eastern part of the basin also exhibited a moderately polluted distribution. In the winter, northern Hami and Karamay in Xinjiang were heavily polluted, and both places are in windy areas, where pollutants are easily transported by strong winds [97]. In general, there are three main strips of moderate $\mathrm{O}_{3}$ pollution outside the country in autumn, which originated in the eastern part of the Aral Sea, the Novosibirsk region of Russia, and the western region of Mongolia. In the spring, the area of the medium potential source of $\mathrm{O}_{3}$ abroad had increased and was widely distributed in East Kazakhstan, Pavlodar, Karaganda, and Almaty. In the summer, the source of $\mathrm{O}_{3}$ was primarily the Altai Territory of Russia, passing through eastern Kazakhstan. The territory was mostly distributed among the surrounding cities of the Irtysh River Valley, and the
WPSCF was between 0.5 and 0.6 . For $\mathrm{NO}_{2}$, the moderately polluted areas were concentrated on the northern slopes of the Tianshan Mountains in autumn. This type of area is the most economically developed in northern Xinjiang and features a high degree of industrialization, and thus it makes an important contribution to regional $\mathrm{NO}_{2}$ emissions [98]. In the winter, Zhundong, Oskemen (Kazakhstan), and Balkhash Lake (Kazakhstan) were heavily polluted. The potential source of $\mathrm{NO}_{2}$ indicated a path conforming to the westerly wind. The $\mathrm{NO}_{2}$ from eastern Kazakhstan is transported eastward through the northern vents of Xinjiang. In addition to the cities on the northern slopes of the Tianshan Mountains, there are moderately polluted areas in the territory in the spring. Heavy pollution sources arise in the northwest of East Kazakhstan and the Altai region in summer. The northwestern part of East Kazakhstan is an industrial agglomeration area; $\mathrm{NO}_{2}$ emissions in this area could be affected by industrial emissions [91]. The WPSCF of the two regions was concentrated at $0.7-0.8$, and the main area was moderately polluted in northern Xinjiang, with the WPSCF value being 0.4-0.5. As far as $\mathrm{SO}_{2}$ is concerned, in autumn there was a moderately polluted source area in northeastern Kazakhstan and the eastern part of the Junggar Basin, whereas other sources in Kazakhstan were only slightly polluted. The main source of $\mathrm{SO}_{2}$ came from external sources in the winter, such as Western Mongolia, eastern Kazakhstan, and Russian border regions. The WPSCF contribution value of this type of region was above 0.5 . In the spring, the potential source of $\mathrm{SO}_{2}$ outside was concentrated in Almaty. Pollutants entered China through the northern vents of Xinjiang, and the source of heavy sulfur dioxide pollution appeared in the background station during the summer. The southern part of Akedala was primarily around the Gurbantunggut Desert area, which could be affected by local oil production emissions [99], and the northern part was mostly affected by the city of Altay. Contaminated areas abroad were mostly transported by cities around the Irtysh River, and their WPSCF values were between 0.4 and 0.6.

In summary, the WPSCF distribution of reactive gases in different seasons was more consistent with the spatial distribution of the probability of trajectory clusters in Section 3.2. Visibly, the source simulated by the PSCF analysis method contributions had greater credibility and could be used for determining potential source contributions. 

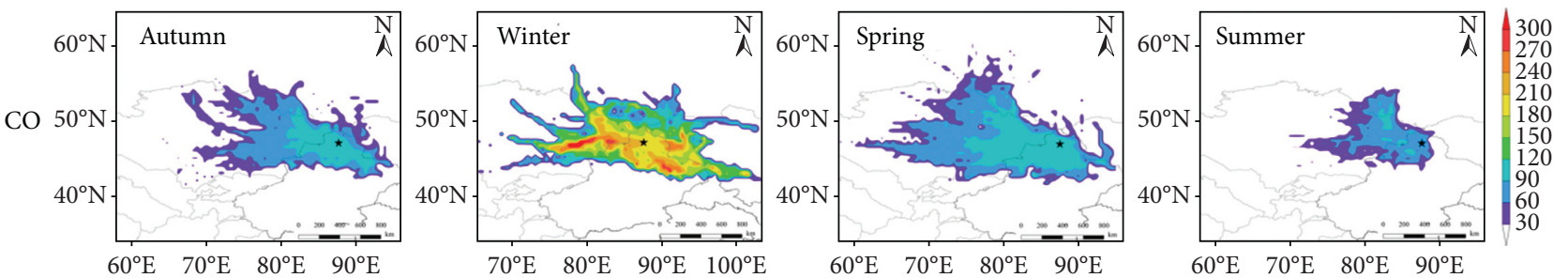

(a)
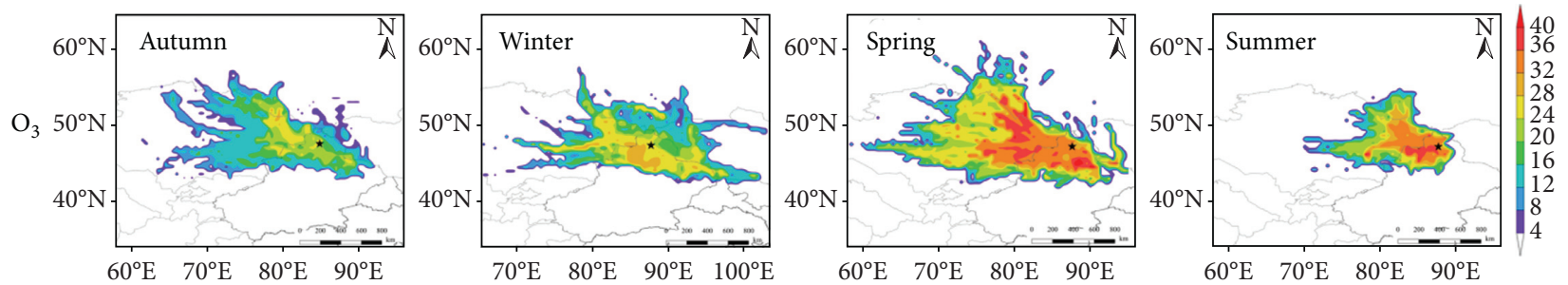

(b)
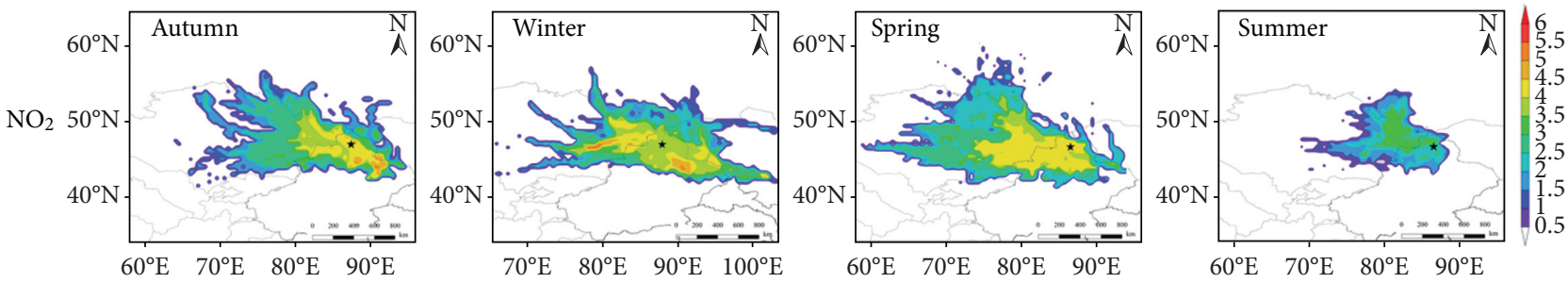

(c)
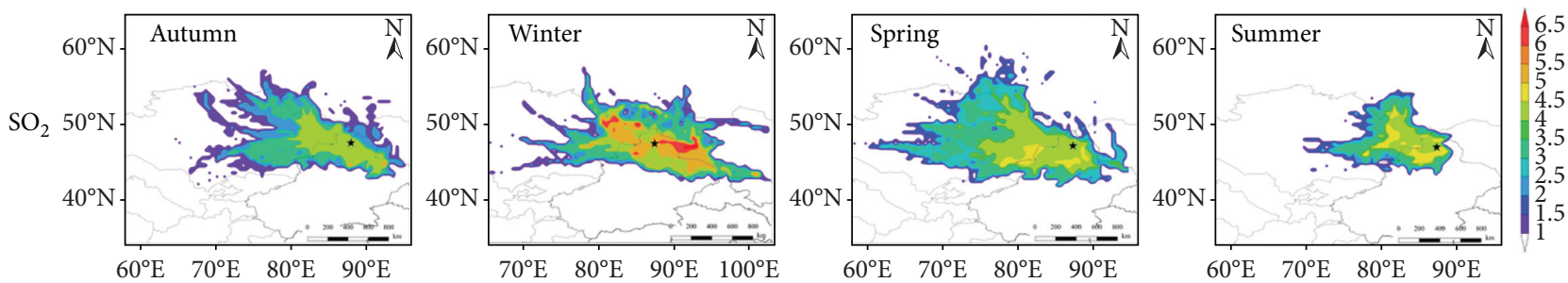

(d)

FIGURE 9: Seasonal distribution of the weighted concentration-weighted trajectory (WCWT) in Akedala, from September 1, 2017, to August 31, 2018. The black star represents Akedala station.

Reactive gases were affected by both local emissions and external sources. Sources of pollution in Xinjiang, eastern Kazakhstan, Southern Russia, and Western Mongolia all made important contributions to Akedala. The PSCF analysis method can only reflect the contribution rate of potential source regions. In other words, the proportion of the pollution trajectory in each grid could not quantitatively reflect the reactive gas mixing ratio [49]. The WCWT was used to simulate the potential source region affecting the Akedala reactive gas mixing ratio value, the results of which are shown in Figure 9.

In terms of CO, the high WCWT areas were concentrated in the Junggar Basin and eastern Kazakhstan in the autumn and spring. The corresponding WCWT values were between 90 and $120 \mathrm{ppb}$. The CO mixing ratio in winter was higher than that during other seasons. The domestic areas were concentrated in northern Xinjiang, where the $\mathrm{CO}$ value was greater than $180 \mathrm{ppb}$. The $\mathrm{CO}$ contribution value in the eastern part of the Junggar Basin was higher, at over $210 \mathrm{ppb}$. The area with a higher WCWT abroad appeared in Lake Balkhash, Kazakhstan, and was greater than $300 \mathrm{ppb}$. The contribution of $\mathrm{CO}$ in the Irtysh River Basin is equivalent to that of Western Mongolia, which was $180-240 \mathrm{ppb}$. In the summer, the contribution of the CO potential source area was the smallest, and the WCWT value was concentrated at 60-90 ppb. For $\mathrm{O}_{3}$, the main source area contribution of $\mathrm{O}_{3}$ was $32-36 \mathrm{ppb}$ in the spring and summer, and the distribution area of high value areas in the summer was smaller than in the spring and was concentrated at $24-28 \mathrm{ppb}$ in the autumn and winter. For $\mathrm{NO}_{2}$, the WCWT value of the main source area of $\mathrm{NO}_{2}$ was relatively low in the summer, ranging from 3 to $3.5 \mathrm{ppb}$, and the $\mathrm{NO}_{2}$ WCWT value of other seasons was between 4 and $4.5 \mathrm{ppb}$. For $\mathrm{SO}_{2}$, the contribution value of the source area in winter was relatively high. The WCWT values in other cities in eastern Kazakhstan and the northern slopes of the Tianshan Mountains were in the range of 5-6.5 ppb. In 
addition, Kobdo in Western Mongolia featured the highest $\mathrm{SO}_{2}$, and its contribution was greater than $6.5 \mathrm{ppb}$. The contribution of WCWT in the $\mathrm{SO}_{2}$ source area in other seasons was $4-5 \mathrm{ppb}$.

\section{Discussion}

A large number of studies have combined various methods such as trajectory statistics, PSCF, and CWT to extensively investigate the potential source areas and transport paths of gaseous pollutants at urban and rural observation sites $[100,101]$, revealing their potential contributing areas and providing important reference for the development of regional air pollution control measures $[9,102,103]$. However, the current research community has paid relatively little attention to the sources of pollution in background areas [1], which are suitable for tracking the sources of atmospheric pollutants because of their sensitivity to environmental changes [18]. Specifically, for the Chinese background stations, the combination of airflow trajectory statistics, PSCF, and CWT reveals that the air trajectory of Shangdianzi GAW station shows a southeastern trend in summer and is mainly affected by the northwestern path in other seasons, which are mainly reflected in the background information of Beijing, Hebei, Tianjin, and Inner Mongolia [104]. Moreover, the Mt Waliguan GAW station mainly reflected the pollution sources of Qinghai, Tibet, and Gansu $[56,57]$. The results of WPSCF show that the overseas potential source areas of $\mathrm{CO}_{2}$ and CO in Shangri-La are mainly located in South Asia, such as Myanmar, Bangladesh, and northern India [105]. The WCWT analysis of atmospheric pollutants (i.e., $\mathrm{SO}_{2}, \mathrm{CO}$, $\mathrm{NO}_{x}, \mathrm{O}_{3}$ ) in the Lin'an area indicates that their major sources may be in the big cities around the observation sites, such as Hangzhou, Shanghai, and Nanjing [106]. Based on WCWT, Luan [107] found that the potential sources of gaseous pollutants in Longfeng Mountain, e.g., $\mathrm{CO}_{2}, \mathrm{CH}_{4}$, and $\mathrm{CO}$, are Harbin and Qiqihar, located in its northwest, and Changchun, Jilin, and Shenyang in its southwest. However, the analysis of the sources of gaseous pollutants in past study was mainly for single pollutants and lacked systematic revelation of the sources of $\mathrm{SO}_{2}, \mathrm{O}_{3}, \mathrm{CO}$, and $\mathrm{NO}_{2}$, the four gaseous pollutants recommended by China Ambient Air Quality Standard (GB3095-2012) [108-110]. Furthermore, several studies have focused on background pollutants in Xinjiang; for example, Wang et al. [111] investigated the pollutants of black carbon, Wang et al. [112] studied the mixing ratio characteristics of ozone, and Liu et al. [53] and Han et al. [113] used satellite product data to invert the aerosol optical thickness and tropospheric ozone column concentrations. However, current studies have paid less attention to the sources of background reactive gases. Based on the reactive gas mixing ratio data observed in situ at the background station and introducing the backward trajectory model, this study systematically investigated the sources of $\mathrm{CO}, \mathrm{SO}_{2}, \mathrm{NO}_{2}$, and $\mathrm{O}_{3}$ in the background region of Xinjiang, China, and foreign pollutants were found to contribute significantly to them, such as Mongolia,
Kazakhstan, and Russia. The reason for this phenomenon may lie in the unique geographical location and meteorological conditions of Akedala, which is in the Irtysh River Valley, where northwesterly winds prevail all year round and pollutants are more easily transported across the borders $[114,115]$. Considering the limitation of this study, i.e., investigating only potential sources of reactive gases, multisource remote sensing data and source emission inventories can be introduced in the future, and further studies on cross-border transport of pollutants in the Xinjiang region can be conducted $[116,117]$. This study provides a valuable reference for monitoring and controlling of the air pollution prevention in Xinjiang region of China by providing an innovative and feasible method.

\section{Conclusions}

In this study, cluster trajectory, PSCF, and CWT methods were used to identify the potential source regions and transportation pathways with reactive gases from August 2017 to September 2018 at Akedala station. On the whole, the annual average (median value) of $\mathrm{O}_{3}, \mathrm{CO}, \mathrm{NO}_{2}$, and $\mathrm{SO}_{2}$ mixing ratios was 29.65 (29.87) ppb, 123.78 (102.75) ppb, 3.79 (3.74) ppb, and 4.59 (4.37) ppb, respectively. The monthly mean values indicated that the high $\mathrm{O}_{3}$ period mainly occurred in February (38.03 ppb), and the high CO and $\mathrm{SO}_{2}$ monthly mean values were related to the heating and coal burning in the winter and peaked in February (208.49 ppb) and January (5.70 ppb). The mixing ratio of $\mathrm{NO}_{2}$ was the highest in March (4.51 ppb).

The cluster analysis showed that the Akedala atmosphere was mainly influenced by air masses from the northwest. The trajectory of airflow outside of China could be divided into three main paths. One originated near Lake Balkhash, the second originated from the eastern Kazakhstan, and the third comprised a shortdistance air mass from the southeast that crossed the Altay Mountains and entered Xinjiang.

According to the results of the PSCF and CWT analysis methods, the high PSCF values of reactive gases were located in eastern Kazakhstan, northern Xinjiang, Western Mongolia, and Southern Russia. The WCWT value of CO was concentrated between 180 and $240 \mathrm{ppb}$ in the winter, and WCWT value of CO was mostly between 90 and $120 \mathrm{ppb}$ in the spring and autumn, whereas the contribution value of the main source region of $\mathrm{CO}$ was the smallest in the summer, at about 60-90 ppb. The WCWT value of $\mathrm{O}_{3}$ in the spring and summer was higher than that in the autumn and winter. The main source area contribution of $\mathrm{O}_{3}$ in the spring and summer was $32-36 \mathrm{ppb}$ and was concentrated at $24-28 \mathrm{ppb}$ in the autumn and winter. The WCWT value of the main source area of $\mathrm{NO}_{2}$ was low in the summer, at 3-3.5 ppb, whereas the WCWT value of $\mathrm{NO}_{2}$ was $4-4.5 \mathrm{ppb}$ during the other seasons. For $\mathrm{SO}_{2}$, the WCWT was highest, at $5-6.5 \mathrm{ppb}$, in the winter. The contribution of WCWT to $\mathrm{SO}_{2}$ sources in the area during the other seasons was 4-5 ppb. 


\section{Data Availability}

Data used in this paper can be obtained from Quanwei Zhao (zqw311403020128@163.com) upon request.

\section{Conflicts of Interest}

The authors declare that they have no conflicts of interest.

\section{Authors' Contributions}

Q. Z., Q. H., and L. J. conceptualized the study and provided research methods; J. W. contributed to data curation; Q. Z. wrote the original draft; Q. Z., Q. H., L. J., and J. W. reviewed and edited the article. Q. H. provided funding acquisition.

\section{Acknowledgments}

This study was sponsored by the Second Tibetan Plateau Scientific Expedition and Research (STEP) Program (Grant no. 2019QZKK010206).

\section{References}

[1] M. Schultz, H. Akimoto, J. Bottenheim et al., "The global atmosphere watch reactive gases measurement network," Elementa: Science of the Anthropocene, vol. 3, p. 000067, 2015.

[2] Y. O. Khaniabadi, G. Goudarzi, S. M. Daryanoosh, A. Borgini, A. Tittarelli, and A. De Marco, "Exposure to $\mathrm{PM}_{10}, \mathrm{NO}_{2}$, and $\mathrm{O}_{3}$ and impacts on human health," Environmental Science and Pollution Research, vol. 24, no. 3, pp. 2781-2789, 2017.

[3] Y. Hu, M. Yao, Y. Liu, and B. Zhao, "Personal exposure to ambient $\mathrm{PM}_{2.5}, \mathrm{PM}_{10}, \mathrm{O}_{3}, \mathrm{NO}_{2}$, and $\mathrm{SO}_{2}$ for different populations in 31 Chinese provinces," Environment International, vol. 144, p. 106018, 2020.

[4] K. Miyazaki, H. J. Eskes, K. Sudo, M. Takigawa, M. Van Weele, and K. F. Boersma, "Simultaneous assimilation of satellite $\mathrm{NO}_{2}, \mathrm{O}_{3}, \mathrm{CO}$, and $\mathrm{HNO}_{3}$ data for the analysis of tropospheric chemical composition and emissions," Atmospheric Chemistry and Physics, vol. 12, no. 20, pp. 9545-9579, 2012.

[5] A. Bigi, F. Bianchi, G. De Gennaro et al., "Hourly composition of gas and particle phase pollutants at a central urban background site in Milan, Italy," Atmospheric Research, vol. 186, pp. 83-94, 2017.

[6] B. Zhao, Y. Su, S. He, M. Zhong, and G. Cui, "Evolution and comparative assessment of ambient air quality standards in China," Journal of Integrative Environmental Sciences, vol. 13, no. 2-4, pp. 1-18, 2016.

[7] J.-S. Swartz, P. G. Van Zyl, J. P. Beukes et al., "Twenty-one years of passive sampling monitoring of $\mathrm{SO}_{2}, \mathrm{NO}_{2}$ and $\mathrm{O}_{3}$ at the cape point GAW station, South Africa," Atmospheric Environment, vol. 222, p. 117128, 2020.

[8] M. T. Woodhouse, A. K. Luhar, L. Stevens et al., "Australian reactive-gas emissions in a global chemistry-climate model and initial results," Air Quality and Climate Change, vol. 49, no. 4, pp. 31-38, 2015.

[9] U. Jeong, J. Kim, H. Lee, and Y. G. Lee, “Assessing the effect of long-range pollutant transportation on air quality in Seoul using the conditional potential source contribution function method," Atmospheric Environment, vol. 150, pp. 33-44, 2017.

[10] G. M. Thornhill, W. J. Collins, R. Y. Kramer et al., "Effective radiative forcing from emissions of reactive gases and aerosols-a multi-model comparison," Atmospheric Chemistry and Physics, vol. 21, no. 2, pp. 853-874, 2021.

[11] Y. Xie, B. Zhao, L. Zhang, and R. Luo, "Spatiotemporal variations of $\mathrm{PM}_{2.5}$ and $\mathrm{PM}_{10}$ concentrations between 31 Chinese cities and their relationships with $\mathrm{SO}_{2}, \mathrm{NO}_{2}, \mathrm{CO}$ and $\mathrm{O}_{3}$," Particuology, vol. 20, pp. 141-149, 2015.

[12] Y. Tian, X. Yao, and L. Chen, "Analysis of spatial and seasonal distributions of air pollutants by incorporating urban morphological characteristics," Computers, Environment and Urban Systems, vol. 75, pp. 35-48, 2019.

[13] Y. Zhu, J. Zhang, J. Wang et al., "Distribution and sources of air pollutants in the north China plain based on on-road mobile measurements," Atmospheric Chemistry and Physics, vol. 16, no. 19, pp. 12551-12565, 2016.

[14] D. Wang, G. Cao, Y. Bai, X. Yang, and Z. Zhang, "Experimental study on the causes and critical conditions of toxic gases in hydraulically fractured oil wells," Energy Sources, Part A: Recovery, Utilization, and Environmental Effects, vol. 42, no. 24, pp. 2963-2971, 2020.

[15] Y. Zhang, X. Yang, R. Brown et al., "Shipping emissions and their impacts on air quality in China," Science of the Total Environment, vol. 581-582, pp. 186-198, 2017.

[16] Z. Wan, S. Ji, Y. Liu, Q. Zhang, J. Chen, and Q. Wang, "Shipping emission inventories in China's Bohai bay, Yangtze river delta, and Pearl river delta in 2018," Marine Pollution Bulletin, vol. 151, p. 110882, 2020.

[17] K. Ali, D. K. Trivedi, and S. K. Sahu, "Surface ozone characterization at Larsemann Hills and Maitri, Antarctica," Science of the Total Environment, vol. 584-585, pp. 11301137, 2017.

[18] IPCC, Climate Change 2013: The Physical Science Basis. Contribution of Working Group I to the Fifth Assessment Report of the Intergovernmental Panel on Climate Change, IPCC, Geneva, Switzerland, 2014.

[19] G. E. Ratto, F. Videla, R. Maronna et al., "Air pollutant transport analysis based on hourly winds in the city of La Plata and surroundings, Argentina," Water, Air, and Soil Pollution, vol. 208, no. 1, pp. 243-257, 2010.

[20] S. A. K. Varma, M. Srimurali, and S. V. K. Varma, "Evolution of wind rose diagrams for RTPP, KADAPA, AP, India," International Journal of Innovative Research and Development, vol. 2, no. 13, p. 2278, 2013.

[21] P. Rai, A. Chakraborty, A. K. Mandariya, and T. Gupta, "Composition and source apportionment of PM1 at urban site Kanpur in India using PMF coupled with CBPF," Atmospheric Research, vol. 178-179, pp. 506-520, 2016.

[22] M. Masiol, S. Squizzato, M. D. Cheng et al., "Differential probability functions for investigating long-term changes in local and regional air pollution sources," Aerosol and Air Quality Research, vol. 19, no. 4, pp. 724-736, 2019.

[23] C. Mangia, E. A. L. Gianicolo, A. Bruni, M. A. Vigotti, and M. Cervino, "Spatial variability of air pollutants in the city of Taranto, Italy and its potential impact on exposure assessment," Environmental Monitoring and Assessment, vol. 185, no. 2, pp. 1719-1735, 2013.

[24] B. Yorkor, T. Leton, and J. Ugbebor, "The role of meteorology for seasonal variation in air pollution level in Eleme, Rivers state, Nigeria," Journal of Scientific Research and Reports, vol. 17, no. 3, pp. 1-17, 2017. 
[25] X. Li, X. Hu, S. Shi, L. Shen, L. Luan, and Y. Ma, "Spatiotemporal variations and regional transport of air pollutants in two urban agglomerations in northeast China plain," Chinese Geographical Science, vol. 29, no. 6, pp. 917-933, 2019.

[26] A. F. Stein, R. R. Draxler, G. D. Rolph, B. J. B. Stunder, M. D. Cohen, and F. Ngan, "NOAA's HYSPLIT atmospheric transport and dispersion modeling system," Bulletin of the American Meteorological Society, vol. 96, no. 12, pp. 20592077, 2015.

[27] Y.-K. Hsu, T. M. Holsen, and P. K. Hopke, "Comparison of hybrid receptor models to locate PCB sources in Chicago," Atmospheric Environment, vol. 37, no. 4, pp. 545-562, 2003.

[28] Y. Q. Wang, X. Y. Zhang, and R. R. Draxler, "TrajStat: GISbased software that uses various trajectory statistical analysis methods to identify potential sources from long-term air pollution measurement data," Environmental Modelling \& Software, vol. 24, no. 8, pp. 938-939, 2009.

[29] C.-F. Ou-Yang, N.-H. Lin, C.-C. Lin et al., "Characteristics of atmospheric carbon monoxide at a high-mountain background station in East Asia," Atmospheric Environment, vol. 89, pp. 613-622, 2014.

[30] K. Vellingiri, K.-H. Kim, J.-M. Lim et al., "Identification of nitrogen dioxide and ozone source regions for an urban area in Korea using back trajectory analysis," Atmospheric Research, vol. 176-177, pp. 212-221, 2016.

[31] S. Kasparoglu, S. Incecik, and S. Topcu, "Spatial and temporal variation of $\mathrm{O}_{3}, \mathrm{NO}$ and $\mathrm{NO}_{2}$ concentrations at rural and urban sites in Marmara Region of Turkey," Atmospheric Pollution Research, vol. 9, no. 6, pp. 1009-1020, 2018.

[32] S. Wang, S. Yu, R. Yan et al., "Characteristics and origins of air pollutants in Wuhan, China, based on observations and hybrid receptor models," Journal of the Air \& Waste Management Association, vol. 67, no. 7, pp. 739-753, 2017.

[33] C. Na, J. Dong-Sheng, C. Jia-Shan et al., "Characteristics of gaseous pollutants at a regional background station in southern China," Atmospheric and Oceanic Science Letters, vol. 7, no. 4, pp. 340-345, 2014.

[34] L. Cheng, D. Ji, J. He et al., "Characteristics of air pollutants and greenhouse gases at a regional background station in southwestern China," Aerosol and Air Quality Research, vol. 19, no. 5, pp. 1007-1023, 2019.

[35] R. Zhao, X. Dou, N. Zhang et al., "The characteristics of inorganic gases and volatile organic compounds at a remote site in the Tibetan Plateau," Atmospheric Research, vol. 234, p. 104740, 2020.

[36] Z. Y. Meng, X. B. Xu, P. Yan et al., "Characteristics of trace gaseous pollutants at a regional background station in northern China," Atmospheric Chemistry and Physics, vol. 9, no. 3, pp. 927-936, 2009.

[37] A. Sharma, T. K. Mandal, S. K. Sharma, D. K. Shukla, and S. Singh, "Relationships of surface ozone with its precursors, particulate matter and meteorology over Delhi," Journal of Atmospheric Chemistry, vol. 74, no. 4, pp. 451-474, 2017.

[38] P. S. Mahapatra, J. Jena, S. Moharana et al., "Surface ozone variation at Bhubaneswar and intra-corelationship study with various parameters," Journal of Earth System Science, vol. 121, no. 5, pp. 1163-1175, 2012.

[39] S. K. Sharma and T. K. Mandal, "Five-year measurements of ambient ammonia and its relationships with other trace gases at an urban site of Delhi, India," Meteorology and Atmospheric Physics, vol. 130, no. 2, pp. 241-257, 2018.

[40] M. Rana, S. K. Mittal, G. Beig et al., "The impact of crop residue burning (CRB) on the diurnal and seasonal variability of the ozone and PM levels at a semi-urban site in the north-western Indo-Gangetic plain," Journal of Earth System Science, vol. 128, no. 6, pp. 1-16, 2019.

[41] N. D. Abdul Halim, M. T. Latif, F. Ahamad et al., "The longterm assessment of air quality on an island in Malaysia," Heliyon, vol. 4, no. 12, p. e01054, 2018.

[42] M. T. Latif, D. Dominick, F. Ahamad et al., "Long term assessment of air quality from a background station on the Malaysian Peninsula," Science of the Total Environment, vol. 482-483, pp. 336-348, 2014.

[43] M. F. Sari, Y. Tasdemir, and F. Esen, "Major air pollutants in Bursa, Turkey: their levels, temporal changes, interactions, and sources," Environmental Forensics, vol. 20, no. 2, pp. 182-195, 2019.

[44] A. Gaur, S. N. Tripathi, V. P. Kanawade, V. Tare, and S. P. Shukla, "Four-year measurements of trace gases $\left(\mathrm{SO}_{2}\right.$, $\mathrm{NO}_{x}, \mathrm{CO}$, and $\mathrm{O}_{3}$ ) at an urban location, Kanpur, in northern India," Journal of Atmospheric Chemistry, vol. 71, no. 4, pp. 283-301, 2014.

[45] D. Rupakheti, X. Yin, M. Rupakheti et al., "Spatio-temporal characteristics of air pollutants over Xinjiang, northwestern China," Environmental Pollution, vol. 268, p. 115907, 2021.

[46] NOAA ARL, Real-Time Environmental Applications and Display System (HYSPLIT), NOAA ARL, College Park, MD, USA, 2007.

[47] L. Makra, I. Matyasovszky, Z. Guba, K. Karatzas, and P. Anttila, "Monitoring the long-range transport effects on urban $\mathrm{PM}_{10}$ levels using 3D clusters of backward trajectories," Atmospheric Environment, vol. 45, no. 16, pp. 2630-2641, 2011.

[48] G. Wang, J. Wang, Y. Xin, and L. Chen, "Transportation pathways and potential source areas of $\mathrm{PM}_{10}$ and $\mathrm{NO}_{2}$ in Tianjin," China Environmental Science, vol. 34, no. 12, pp. 3009-3016, 2014.

[49] N. Liu, Y. Yu, J. He, and S. Zhao, "Integrated modeling of urban-scale pollutant transport: application in a semi-arid urban valley, northwestern China," Atmospheric Pollution Research, vol. 4, no. 3, pp. 306-314, 2013.

[50] C. Peng, M. Tian, Y. Chen et al., "Characteristics, formation mechanisms and potential transport pathways of $\mathrm{PM}_{2.5}$ at a rural Background Site in Chongqing, Southwest China," Aerosol and Air Quality Research, vol. 19, no. 9, pp. 19801992, 2019.

[51] L. L. Ashbaugh, W. C. Malm, and W. Z. Sadeh, "A residence time probability analysis of sulfur concentrations at Grand Canyon National Park," Atmospheric Environment, vol. 19, no. 8, pp. 1263-1270, 1985.

[52] Y. Q. Wang, X. Y. Zhang, and R. Arimoto, "The contribution from distant dust sources to the atmospheric particulate matter loadings at Xian, China during spring," Science of the Total Environment, vol. 368, no. 2-3, pp. 875-883, 2006.

[53] N. Liu, W. Lin, J. Ma, W. Xu, and X. Xu, "Seasonal variation in surface ozone and its regional characteristics at global atmosphere watch stations in China," Journal of Environmental Sciences, vol. 77, pp. 291-302, 2019.

[54] N. Liu, J. Ma, W. Xu, Y. Wang, A. Pozzer, and J. Lelieveld, “A modeling study of the regional representativeness of surface ozone variation at the WMO/GAW background stations in China," Atmospheric Environment, vol. 242, p. 117672, 2020.

[55] Y. Chen, Q. Ma, W. Lin, X. Xu, J. Yao, and W. Gao, "Measurement report: long-term variations in carbon monoxide at a background station in China's Yangtze river delta region," Atmospheric Chemistry and Physics Discussions, vol. 20, no. 24, pp. 15969-15982, 2020. 
[56] M. Guo, S. Fang, S. Liu et al., "Comparison of atmospheric $\mathrm{CO}_{2}, \mathrm{CH}_{4}$, and $\mathrm{CO}$ at two stations in the Tibetan Plateau of China," Earth and Space Science, vol. 7, no. 5, p. e2019EA001051, 2020.

[57] J. Ma, S. Dörner, S. Donner et al., "MAX-DOAS measurements of $\mathrm{NO}_{2}, \mathrm{SO}_{2}, \mathrm{HCHO}$, and $\mathrm{BrO}$ at the Mt. Waliguan WMO GAW global baseline station in the Tibetan Plateau," Atmospheric Chemistry and Physics, vol. 20, no. 11, pp. 6973-6990, 2020.

[58] H. Qi, W. Lin, X. Xu, X. Yu, and Q. Ma, "Significant downward trend of $\mathrm{SO}_{2}$ observed from 2005 to 2010 at a background station in the Yangtze Delta region, China," Science China Chemistry, vol. 55, no. 7, pp. 1451-1458, 2012.

[59] Z. Y. Meng, X. B. Xu, T. Wang et al., "Ambient sulfur dioxide, nitrogen dioxide, and ammonia at ten background and rural sites in China during 2007-2008," Atmospheric Environment, vol. 44, no. 21-22, pp. 2625-2631, 2010.

[60] W. Lin, X. Xu, X. Yu, X. Zhang, and J. Huang, "Observed levels and trends of gaseous $\mathrm{SO}_{2}$ and $\mathrm{HNO}_{3}$ at Mt. Waliguan, China: results from 1997 to 2009," Journal of Environmental Sciences, vol. 25, no. 4, pp. 726-734, 2013.

[61] N. Liu and J. Ma, "Seasonal relationships of tropospheric ozone and its precursors over East Asia," Journal of Applied Meteorological Science, vol. 28, pp. 427-435, 2017.

[62] J. Hsu and M. J. Prather, "Stratospheric variability and tropospheric ozone," Journal of Geophysical Research, vol. 114, no. 6, p. D06102, 2009.

[63] F. Zhang, L. X. Zhou, P. C. Novelli et al., "Evaluation of in situ measurements of atmospheric carbon monoxide at Mount Waliguan, China," Atmospheric Chemistry and Physics, vol. 11, no. 11, pp. 5195-5206, 2011.

[64] A. Kerimray, B. Kenessov, and F. Karaca, "Retracted article: trends and health impacts of major urban air pollutants in Kazakhstan," Journal of the Air \& Waste Management Association, vol. 69, no. 11, pp. 1331-1347, 2019.

[65] Y. L. Wu, H. H. Xu, and D. J. Yu, "Characteristics of carbon monoxide concentration in atmospheric background station in Longfengshan area," Environmental Chemistry, vol. 27, no. 6, pp. 847-848, 2008, in Chinese.

[66] S. Liu, S. Fang, M. Liang, W. Sun, and Z. Feng, "Temporal patterns and source regions of atmospheric carbon monoxide at two background stations in China," Atmospheric Research, vol. 220, pp. 169-180, 2019.

[67] Z. Darynova, A. Maksot, L. Kulmukanova et al., "Evaluation of $\mathrm{NO}_{2}$ column variations over the atmosphere of Kazakhstan using satellite data," Journal of Applied Remote Sensing, vol. 12, no. 4, p. 042610, 2018.

[68] X. M. Yu, "Variation characteristics of $\mathrm{SO}_{2}$ concentration in Linan region atmospheric background station from 2006 to 2008," in Proceedings of the 27th Annual Meeting of Chinese Meteorological Society, Beijing, China, pp. 1-4, 2012, in Chinese.

[69] T. L. Zhao, D. Liu, T. Li et al., "Progress of study on atmospheric pollutant emissions from agricultural activity and their effect on atmospheric environment," Engineering Science and Technology, vol. 16, pp. 144-152, 2016, in Chinese.

[70] R. B. Stull, An Introduction to Boundary Layer Meteorology, Springer Science \& Business Media, Berlin, Germany, 1988.

[71] M. Luo, X. Hou, Y. Gu et al., "Trans-boundary air pollution in a city under various atmospheric conditions," Science of The Total Environment, vol. 168, pp. 132-141, 2018.

[72] L. Han, W. Zhou, W. Li et al., "Meteorological and urban landscape factors on severe air pollution in Beijing," Journal of the Air and Waste Management Association, vol. 165, no. 7, pp. 782-787, 2015.

[73] Y. Zhang, "Dynamic effect analysis of meteorological conditions on air pollution: a case study from Beijing," Science of the Total Environment, vol. 684, pp. 178-185, 2019.

[74] Y. Kim and J. Y. Guldmann, "Impact of traffic flows and wind directions on air pollution concentrations in Seoul, Korea," Atmospheric Environment, vol. 45, no. 16, pp. 2803-2810, 2011.

[75] M. L. Akinyemi, M. E. Emetere, and S. A. Akinwumi, "Dynamics of wind strength and wind direction on air pollution dispersion," Asian Journal of Applied Sciences, vol. 4, no. 2, pp. 422-429, 2016.

[76] F. Pan, C. Tian, F. Shao, W. Zhou, and F. Chen, "Evaluation of ecological sensitivity in Karamay, Xinjiang, China," Journal of Geographical Sciences, vol. 22, no. 2, pp. 329-345, 2012.

[77] H. Li, S. You, H. Zhang, W. Zheng, and L. Zou, "Investigating the environmental quality deterioration and human health hazard caused by heating emissions," Science of the Total Environment, vol. 628-629, pp. 1209-1222, 2018.

[78] N. Zhang, X. Zhao, T. Liu et al., "Layout planning of highway transportation environment monitoring network: the case of Xinjiang, China," Sustainability, vol. 12, no. 1, p. 290, 2020.

[79] C. Sun, Y. Luo, and J. Li, "Urban traffic infrastructure investment and air pollution: evidence from the 83 cities in China," Journal of Cleaner Production, vol. 172, pp. 488-496, 2018.

[80] Z. Li, Y. Wang, Z. Xu, and Y. e. Cao, "Characteristics and sources of atmospheric pollutants in typical inland cities in arid regions of central Asia: a case study of Urumqi city," PLoS One, vol. 16, no. 4, p. e0249563, 2021.

[81] Y. Liu, C. Wu, R. Jia, and J. Huang, "An overview of the influence of atmospheric circulation on the climate in arid and semi-arid region of Central and East Asia," Science China Earth Sciences, vol. 61, no. 9, pp. 1183-1194, 2018.

[82] X. Q. Zhou, L. Yang, and L. F. Yang, "Estimation and analysis of emissions from agricultural non-point source pollution in Xinjiang," Journal of Agro-Environment Science, vol. 36, no. 7, pp. 1300-1307, 2017.

[83] S. Zhang, W. F. Pu, D. D. Liu et al., "Cause analysis on excess production of carbon monoxide in cyclic steam stimulation process-taking Hongshan oilfield as example," Journal of Safety Science and Technology, vol. 12, no. 8, pp. 153-157, 2016, in Chinese.

[84] A. K. Sharma and K. A. Siddiqui, "Assessment of air quality for an open cast coal mining area," Indian Journal of Scientific Research, vol. 1, no. 2, pp. 47-55, 2010.

[85] X. J. Sun, P. X. Wang, and J. X. L. Wang, "An assessment of the atmospheric centers of action in the northern hemisphere winter," Climate Dynamics, vol. 48, no. 3-4, pp. 1031-1047, 2017.

[86] T. Alimbaev, B. Omarova, B. Abzhapparova, K. Ilyassova, K. Yermagambetova, and Z. Mazhitova, "Environment of East Kazakhstan: state and main directions of optimization," E3S Web of Conferences, vol. 175, p. 14008, 2020.

[87] M.-E. Luvsan, R.-H. Shie, T. Purevdorj, L. Badarch, B. Baldorj, and C.-C. Chan, "The influence of emission sources and meteorological conditions on $\mathrm{SO}_{2}$ pollution in Mongolia," Atmospheric Environment, vol. 61, pp. 542-549, 2012.

[88] B. McKuin and J. E. Campbell, "Emissions and climate forcing from global and Arctic fishing vessels," Journal of 
Geophysical Research: Atmospheres, vol. 121, no. 4, pp. 1844-1858, 2016.

[89] Y. Zhou, X. Xing, J. Lang et al., "A comprehensive biomass burning emission inventory with high spatial and temporal resolution in China," Atmospheric Chemistry and Physics, vol. 17, no. 4, pp. 2839-2864, 2017.

[90] L. Nugumanova, M. Frey, N. Yemelina, and S. Yugay, Environmental Problems and Policies in Kazakhstan: Air Pollution, Waste and Water (No. 366), IOS Working Papers, Regensburg, Germany, 2017.

[91] D. Assanov, V. Zapasnyi, and A. Kerimray, "Air Quality and industrial emissions in the cities of Kazakhstan," Atmosphere, vol. 12, no. 3, p. 314, 2021.

[92] S. Abdul-Wahab, S. Ali, S. Sardar, and N. Irfan, "Impacts on ambient air quality due to flaring activities in one of Oman's oilfields," Archives of Environmental \& Occupational Health, vol. 67 , no. 1, pp. 3-14, 2012.

[93] E. E. McDuffie, P. M. Edwards, J. B. Gilman et al., "Influence of oil and gas emissions on summertime ozone in the Colorado northern front range," Journal of Geophysical Research: Atmospheres, vol. 121, no. 14, pp. 8712-8729, 2016.

[94] Y. Liang, X. Liu, F. Wu, Y. Guo, X. Fan, and H. Xiao, "The year-round variations of VOC mixing ratios and their sources in Kuytun City (northwestern China), near oilfields," Atmospheric Pollution Research, vol. 11, no. 9, pp. 1513-1523, 2020.

[95] D. Ye and Y. C. Zhang, "Association of concurrent variation between the East Asian polar front and subtropical jets with winter cold air activity in China," Chinese Journal of Atmospheric Sciences, vol. 38, no. 1, pp. 146-158, 2014.

[96] A. Hamidov, K. Helming, and D. Balla, "Impact of agricultural land use in Central Asia: a review," Agronomy for Sustainable Development, vol. 36, no. 1, p. 6, 2016.

[97] X.-Y. An, Z. Yan, and J.-M. Jia, "A new distribution for modeling wind speed characteristics and evaluating wind power potential in Xinjiang, China," Energy Sources, Part A: Recovery, Utilization, and Environmental Effects, pp. 1-19, 2020.

[98] J. Yan, Y. H. Li, and Y. P. Ma, "Study on temporal and spatial variation of atmospheric $\mathrm{NO}_{2}$ and $\mathrm{SO}_{2}$ and analysis of influencing factors in valley-type cities on the northern slope of Tianshan mountains," Journal of Ecology and Rural Environment, vol. 36 , no. 10, pp. 1268-1275, 2020, in Chinese.

[99] K. H. Li, W. Song, X. J. Liu et al., "Atmospheric reactive nitrogen concentrations at ten sites with contrasting land use in an arid region of central Asia," Biogeosciences, vol. 9, no. 10, pp. 4013-4021, 2012.

[100] Z. L. Fleming, P. S. Monks, and A. J. Manning, "Review: untangling the influence of air-mass history in interpreting observed atmospheric composition," Atmospheric Research, vol. 104-105, pp. 1-39, 2012.

[101] J.-E. Petit, O. Favez, A. Albinet, and F. Canonaco, "A userfriendly tool for comprehensive evaluation of the geographical origins of atmospheric pollution: wind and trajectory analyses," Environmental Modelling \& Software, vol. 88, pp. 183-187, 2017.

[102] A. A. Donnelly, B. M. Broderick, and B. D. Misstear, "The effect of long-range air mass transport pathways on $\mathrm{PM}_{10}$ and $\mathrm{NO}_{2}$ concentrations at urban and rural background sites in Ireland: quantification using clustering techniques," Journal of Environmental Science and Health, Part A, vol. 50, no. 7, pp. 647-658, 2015.

[103] K. A. Shukurov, A. N. Borovski, A. V. Dzhola et al., "Potential sources of reactive gases for the west of Moscow
Oblast," in Proceedings of the 2018 Remote Sensing of Clouds and the Atmosphere XXIII, Berlin, Germany, September 2018.

[104] L. Liu, P. P. Tans, L. Xia, L. Zhou, and F. Zhang, "Analysis of patterns in the concentrations of atmospheric greenhouse gases measured in two typical urban clusters in China," Atmospheric Environment, vol. 173, pp. 343-354, 2018.

[105] S. Fang, P. P. Tans, M. Steinbacher, L. Zhou, T. Luan, and Z. Li, "Observation of atmospheric $\mathrm{CO}_{2}$ and $\mathrm{CO}$ at ShangriLa station: results from the only regional station located at southwestern China," Tellus B: Chemical and Physical Meteorology, vol. 68, no. 1, p. 28506, 2016.

[106] Y. Yue, Variation Characteristics of $P M_{10}$ and Reactive Gases and its Influencing Factors at Lin an Regional Background Station in Yangtze River Delta Region, Guizhou University, Guiyang, China, 2017, in Chinese.

[107] T. Luan, Study on Concentration Characteristics and Emission/sink of Greenhouse Gases at Longfengshan Regional Background Station in Heilongjiang Province of China, Chinese Academy of Meteorological Sciences, Beijing, China, 2015, in Chinese.

[108] F. Chai, J. Gao, Z. Chen et al., "Spatial and temporal variation of particulate matter and gaseous pollutants in 26 cities in China," Journal of Environmental Sciences, vol. 26, no. 1, pp. 75-82, 2014.

[109] R. Li, L. Cui, J. Li et al., "Spatial and temporal variation of particulate matter and gaseous pollutants in China during 2014-2016," Atmospheric Environment, vol. 161, pp. 235-246, 2017.

[110] X. Ma, H. Jia, T. Sha, J. An, and R. Tian, "Spatial and seasonal characteristics of particulate matter and gaseous pollution in China: implications for control policy," Environmental Pollution, vol. 248, pp. 421-428, 2019.

[111] H. Wang, Q. He, T. Liu et al., "Characteristics and source of black carbon aerosols at Akedala station, Central Asia," Meteorology and Atmospheric Physics, vol. 118, no. 3, pp. 189-197, 2012.

[112] H. Wang, J. Ma, Y. Shen, and Y. Wang, “Assessment of ozone variations and meteorological influences at a rural site in northern Xinjiang," Bulletin of Environmental Contamination and Toxicology, vol. 94, no. 2, pp. 240-246, 2015.

[113] X. Han, X. Zou, Z. Song, D. Fu, X. Xia, and H. Che, "Comparison of AVHRR aerosol optical depth production against CARSNET data in China," Atmospheric Research, vol. 218, pp. 12-24, 2019.

[114] C. Genfa, G. Xuerui, Z. Qiuxia et al., "Temporal and spatial variation of wind speed of Xinjiang, China," in Proceedings of the 2011 International Conference on Electrical and Control Engineering, pp. 6135-6137, Yichang, China, September 2011.

[115] C. Xu, J. Li, J. Zhao, S. Gao, and Y. Chen, "Climate variations in northern Xinjiang of China over the past 50 years under global warming," Quaternary International, vol. 358, pp. 83-92, 2015.

[116] J. Zhang, "Multi-source remote sensing data fusion: status and trends," International Journal of Image and Data Fusion, vol. 1, no. 1, pp. 5-24, 2010.

[117] H. Huo, Q. Zhang, D. Guan, X. Su, H. Zhao, and K. He, "Examining air pollution in China using production- and consumption-based emissions accounting approaches," Environmental Science \& Technology, vol. 48, no. 24, pp. 14139-14147, 2014. 